\title{
24-Epibrassinolide mitigates nickel toxicity in young Eucalyptus urophylla S.T. Blake plants: nutritional, physiological, biochemical, anatomical and morphological responses
}

\author{
Alaene Teixeira Ribeiro ${ }^{1}$ - Victor Pereira de Oliveira ${ }^{1}$. Udson de Oliveira Barros Junior ${ }^{1}$. \\ Breno Ricardo Serrão da Silva ${ }^{1} \cdot$ Bruno Lemos Batista $^{2}$ • Allan Klynger da Silva Lobato ${ }^{1}$ (B)
}

Received: 6 June 2019 / Accepted: 27 November 2019 / Published online: 10 January 2020

(C) INRA and Springer-Verlag France SAS, part of Springer Nature 2020

\begin{abstract}
- Key message Our research revealed that 24-epibrassinolide alleviated nickel toxicity in young Eucalyptus urophylla plants, inducing benefits on nutritional, physiological, biochemical, anatomical and morphological responses.

- Context Soil contamination by heavy metals may limit the Eucalyptus production. Disturbances caused by nickel (Ni) toxicity interfere with the absorption of other essential nutrients. 24-Epibrassinolide (EBR) is one form of brassinosteroid (BR) that provides benefits for plant metabolism under Ni toxicity.

- Aims The aim of this study was to determine whether exogenous EBR can improve ionic homeostasis by evaluating nutrient concentrations, anatomical characteristics and chlorophyll fluorescence in young Eucalyptus urophylla plants subjected to $\mathrm{Ni}$ toxicity.

- Methods The experiment was randomized into four treatments, including two Ni concentrations ( 0 and $600 \mu \mathrm{M} \mathrm{Ni})$ and two 24epibrassinolide concentrations ( 0 and $100 \mathrm{nM}$ EBR).

- Results EBR significantly reduced $\mathrm{Ni}$ contents. Plants exposed to $\mathrm{Ni}^{2+}$ and sprayed with steroid had increases in the $\mathrm{Ca}^{2+} \mathrm{Ni}^{2+}$ and $\mathrm{Mn}^{2+} \mathrm{Ni}^{2+}$ ratios in the leaves of $38 \%$ and $15 \%$, respectively, compared with the same treatment without $\mathrm{EBR}$. The treatment of $\mathrm{Ni}^{2+}$ toxicity $+\mathrm{EBR}$ presented an increase of $42 \%$ in effective quantum yield of PSII photochemistry, when compared with plants exposed to Ni without EBR. Ni toxicity induced negative effects on stomatal functionality, but EBR application mitigated these effects.

- Conclusion Benefits on effective quantum yield of PSII photochemistry after EBR spray can be related to increases in manganese contents. EBR reduced oxidative stress, alleviating the deleterious effects induced by Ni toxicity and inducing positive repercussions on antioxidant enzymes, photosynthetic pigments and biomass.
\end{abstract}

Keywords Eucalyptus urophylla $\cdot$ Light capture $\cdot$ Metal contamination $\cdot$ Nutritional balance $\cdot 24$-epibrassinolide

\begin{tabular}{|c|c|c|c|}
\hline \multicolumn{2}{|c|}{ Abbreviations } & EDS & Equatorial diameter of the stomata \\
\hline \multirow{5}{*}{$\begin{array}{l}\mathrm{BR} \\
C_{\mathrm{i}} \\
E \\
\mathrm{~EB}\end{array}$} & Brassinosteroids & EL & Electrolyte leakage \\
\hline & Intercellular $\mathrm{CO}_{2}$ concentration & ETAb & Epidermis thickness from abaxial leaf side \\
\hline & Transpiration rate & ETAd & Epidermis thickness from adaxial leaf side \\
\hline & 24-epibrassinolide & ETR & Electron transport rate \\
\hline & & $\mathrm{ETR} / P_{\mathrm{N}}$ & Ratio between the apparent electron transport \\
\hline \multicolumn{2}{|c|}{ Handling Editor: Erwin Dreyer } & & \\
\hline \multicolumn{2}{|c|}{$\begin{array}{l}\triangle \text { Allan Klynger da Silva Lobato } \\
\text { allanllobato@yahoo.com.br }\end{array}$} & $\begin{array}{l}\text { Exc } \\
\mathrm{F}_{0}\end{array}$ & $\begin{array}{l}\text { Minimal fluorescence yield of the } \\
\text { dark-adapted state }\end{array}$ \\
\hline & \multirow[b]{2}{*}{$\begin{array}{l}\text { Núcleo de Pesquisa Vegetal Básica e Aplicada, Universidade Federal } \\
\text { Rural da Amazônia, Rodovia PA 256, Paragominas, Pará, Brazil }\end{array}$} & $\mathrm{Fe}$ & Iron \\
\hline & & $\mathrm{F}_{\mathrm{m}}$ & Maximal fluorescence yield of the \\
\hline & $\begin{array}{l}\text { Centro de Ciências Naturais e Humanas, Universidade Federal do } \\
\text { ABC, Santo André, São Paulo, Brazil }\end{array}$ & $\mathrm{F}_{\mathrm{v}}$ & $\begin{array}{l}\text { dark-adapted state } \\
\text { Variable fluorescence }\end{array}$ \\
\hline
\end{tabular}




$\begin{array}{ll}\mathrm{F}_{\mathrm{v}} / \mathrm{F}_{\mathrm{m}} & \text { Maximal quantum yield of PSII photochemistry } \\ \text { NPQ } & \text { Nonphotochemical quenching } \\ \text { NRAMP } & \text { Natural resistance-associated macrophage protein } \\ \text { PDS } & \text { Polar diameter of the stomata } \\ P_{\mathrm{N}} & \text { Net photosynthetic rate } \\ P_{\mathrm{N}} / C_{\mathrm{i}} & \text { Instantaneous carboxylation efficiency } \\ \mathrm{PPT} & \text { Palisade parenchyma thickness } \\ \mathrm{q}_{\mathrm{P}} & \text { Photochemical quenching } \\ \mathrm{RCD} & \text { Root cortex diameter } \\ \mathrm{RDM} & \text { Root dry matter } \\ \text { RMD } & \text { Root metaxylem diameter } \\ \text { RDT } & \text { Root endodermis thickness } \\ \text { RET } & \text { Root epidermis thickness } \\ \text { SD } & \text { Stomatal density } \\ \text { SDM } & \text { Stem dry matter } \\ \text { SF } & \text { Stomatal functionality } \\ \text { SI } & \text { Stomatal index } \\ \text { SPT } & \text { Spongy parenchyma thickness } \\ \text { TDM } & \text { Total dry matter } \\ \text { Total Chl } & \text { Total chlorophyll } \\ \text { VCD } & \text { Vascular cylinder diameter } \\ \text { WUE } & \text { Water-use efficiency } \\ \text { ZIP } & \text { ZRT/IRT-like protein } \\ \Phi_{\mathrm{PSII}} & \text { Effective quantum yield of PSII photochemistry }\end{array}$

\section{Introduction}

The growing demand for wood accompanied by a reduction in the supply of the remaining natural forests has influenced the rapid expansion of plantations, in which Eucalyptus plays an important role, particularly in Brazil (Tadele and Teketay 2014). This genus comprises of species that present a broad adaptability to different types of soils and climates, rapid growth and multiple uses of the wood (Jenbere et al. 2012; Neiva et al. 2015). Eucalyptus plantations cover over more than 20 million hectares in tropical and temperate regions around the world (Mora et al. 2017). In 2016, Brazil had a better position in the global ranking of forestry yield $\left(35.7 \mathrm{~m}^{3} \mathrm{ha}^{-1}\right.$ per year), cultivating an area of approximately 5.7 million ha with planted trees (IBÁ 2017).

Soil contamination by heavy metals may limit Eucalyptus production in field conditions. Nickel (Ni) is one of the heavy metals most frequently found in the environment (Ashraf et al. 2011; Vázquez et al. 2013; Hussain et al. 2013), and high Ni concentrations have been described in ultramafic soils or polluted soils, with occurrence also in Brazil (Reeves et al. 2007). In Brazil, areas with ultramafic soils have been used Eucalyptus during phytoremediation process and consequent $\mathrm{Ni}$ extraction from soil, because this gender presents higher tolerance to heavy metals, comparing with other species (Gomes et al. 2012; Korzeniowska and StanislawskaGlubiak 2019). The causes of environmental contamination provoked by Ni can be natural or anthropogenic (Harasim and Filipek 2015), natural causes include mainly the weathering of ultrabasic igneous rocks (Yusuf et al. 2011b), while anthropogenic causes include an intensification of industrialisation processes and urbanization (Nagajyoti et al. 2010).

$\mathrm{Ni}$ in excess causes toxic effects on plants, causing damage to tissues and negative interferences in plant metabolism (Yusuf et al. 2011b; Bazihizina et al. 2015). The indicators most commonly found for Ni phytotoxicity include inhibition of germination, leaf necrosis, root system reduction, organ deformation and reduced growth (Nie et al. 2015; Kuramshina et al. 2018). Excess Ni affects several physiological and biochemical processes in higher plants (Amari et al. 2014), including reductions of gas exchange (Velikova et al. 2011) and decreases in chlorophyll levels (Sirhindi et al. 2016).

Disturbances induced by $\mathrm{Ni}^{2+}$ toxicity frequently cause interferences on uptake of other essential nutrients, such as $\mathrm{Ca}^{2+}$ and $\mathrm{Mn}^{2+}$ (Pandey and Sharma 2002; Chen et al. 2009; Nishida et al. 2011; Saad et al. 2016), because these elements are assimilated in the form of divalent cations (Yusuf et al. 2011a; Sharma and Dhiman 2013). More specifically, Ni can negatively affects the concentration and availability of cytosolic $\mathrm{Ca}^{2+}$, which is a secondary messenger involved in the signalling and regulation of the stomatal opening in plants (Laanemets et al. 2013; Edel and Kudla 2016). In addition, $\mathrm{Ni}^{2+}$ can also inhibit the absorption of $\mathrm{Mn}^{2+}$, reducing the photosynthesis because the $\mathrm{Mn}^{2+}$ integrates the catalytic agglomerate of the oxygen evolution complex of photosystem II, in which light energy is used for photosynthetic oxidation of intracellular water and oxygen formation (Shutilova 2010; Schmidt et al. 2016; Gao et al. 2018).

Ionic homeostasis corresponds to the condition that the nutrients are in equilibrium in plant tissues (Rouached et al. 2010), but Ni toxicity frequently induces damages on transporter proteins and membrane disruption (Mizuno et al. 2005), provoking imbalances on element contents that are essentials to adequate growth and development (Seregin and Kozhevnikova 2006). Matraszek et al. (2016) studying the $\mathrm{Ni}$ effects on Triticum aestivum described substantial reductions on macro and micronutrients in root and shoot tissues.

The root is a tissue with intense interactions during stress situations induced by heavy metals, causing cellular disorganization and negatively affecting the uptake, transport and accumulation of water and nutrients (Aroca et al. 2012; Garcia et al. 2018). In this context, the vascular cylinder is a structure composed of xylem and phloem, highly vascularized and intrinsically related to the transport of solubilized elements and organic solutes, respectively (Mellor et al. 2017). On the other hand, the leaf represents a tissue highly sensitive and responsive to intoxication by metals, including $\mathrm{Ni}$ (Djebali et al. 2005; Pérez Chaca et al. 2014; Santos et al. 
2017). Epidermis is often considered as an efficient protective structure (Javelle et al. 2011), while the palisade and spongy parenchyma are structures linked to the diffusion and distribution of $\mathrm{CO}_{2}$, being the photosynthetic process depends of the $\mathrm{CO}_{2}$ supply (Poorter et al. 2009).

One of the methods used to decrease the toxic effect of excess heavy metals is the exogenous application of and/or manipulation of the endogenous concentration of brassinosteroids (BRs) (Bajguz and Hayat 2009; Lima et al. 2018). BRs are molecules of polyhydroxylated steroids with broad biological activity (Choudhary et al. 2012; Bajguz and Piotrowska-Niczyporuk 2014). The 24-epibrassinolide (EBR) is the form most bioactive of plant steroid, playing key roles in growth and development (Fariduddin et al. 2014; Seldimirova et al. 2017), including vascular differentiation (Ibanes et al. 2009) and cell elongation in different organs and tissues (Gudesblat and Russinova 2011; Choudhary et al. 2012). Additionally, several studies have proven that these steroids have multiple effects (direct and indirect), contributing on modulation of gene expression (Sharma et al. 2017), maintenance of the photochemical efficiency of the PSII (Lima and Lobato 2017), increases linked to gas exchange (Santos et al. 2018), maximization of photosynthetic pigments (Siddiqui et al. 2018) and alleviation of oxidative stress (Ahammed et al. 2013a).

Our hypothesis was based on the reductions induced by $\mathrm{Ni}$ toxicity on nutrient contents and consequently ionic homeostasis (Ahmad et al. 2007; Deng et al. 2016). In addition, there are interesting evidences that EBR can mitigate the effects caused by the toxicity of metals, including Ni. Ali et al. (2008) studying Brassica juncea plants verified increments on photosynthetic pigments and gas exchange. Yusuf et al. (2012) detected increases in enzyme activities of the antioxidant system in Vigna radiata plants. Soares et al. (2016) reported that EBR enhanced the growth of Solanum nigrum plants. Lukatkin et al. (2013) also observed positive repercussions on the seed germination rate of Zea mays seedlings. In this context, the aim of this study was to determine whether exogenous EBR can improve homeostasis by evaluating the responses associated with nutrient concentrations, anatomical characteristics, gas exchange and chlorophyll fluorescence in young Eucalyptus urophylla plants subjected to Ni toxicity.

\section{Materials and methods}

\subsection{Location and growth conditions}

The experiment was performed at the Campus of Paragominas of the Universidade Federal Rural da Amazônia, Paragominas, Brazil $\left(2^{\circ} 55^{\prime} \mathrm{S}, 47^{\circ} 34^{\prime} \mathrm{W}\right)$. The study was conducted in a greenhouse with the temperature and humidity controlled. The minimum, maximum and median temperatures were 28,33 and $26.9^{\circ} \mathrm{C}$, respectively. The relative humidity during the experimental period varied between 60 and $80 \%$. Average maximum photosynthetic photon flux density was $755 \mu \mathrm{mol} \mathrm{m}^{-2} \mathrm{~s}^{-1}$ (plant canopy), and photoperiod of $12 \mathrm{~h}$.

\subsection{Plants, containers and acclimation}

Forty-five-day-old E. urophylla plants were selected and placed in 1.2-L containers filled with sand and vermiculite in a 3:1 ratio. Plants were cultivated under semi-hydroponic conditions containing $500 \mathrm{~mL}$ of nutritive solution, being the solution absorption by capillarity in agreement with Lima et al. (2018). Modified Hoagland and Arnon (1950) solution was used as a source of nutrients; the ionic strength started at $50 \%$ (45th day) and was modified to $100 \%$ after 5 days (50th day).

\subsection{Experimental design}

The experiment was randomized with four treatments, including two $\mathrm{Ni}$ concentrations $(0$ and $600 \mu \mathrm{M} \mathrm{Ni}$, described as $\mathrm{Ni}^{2+}$ and $+\mathrm{Ni}^{2+}$, respectively) and two concentrations of brassinosteroids (0 and $100 \mathrm{nM}$ EBR, described as-EBR and + EBR, respectively). The experiment comprised five replicate individuals per treatment.

\subsection{4-epibrassinolide (EBR) preparation and application}

Fifty-five-day-old plants were sprayed with 24-epibrassinolide (EBR) or Milli-Q water (containing a proportion of ethanol that was equal to that used to prepare the EBR solution) at 5-day intervals until day 85. The 0 and $100 \mathrm{nM} \mathrm{EBR}$ (Sigma-Aldrich, USA) solutions were prepared by dissolving the solute in ethanol followed by dilution with Milli-Q water [ethanol:water $(\mathrm{v} / \mathrm{v})=1: 10,000]$ (Ahammed et al. 2013b).

\subsection{Plant nutrition and Ni treatment}

The plants received the following macro- and micro-nutrients contained in the nutrient solution: $8.75 \mathrm{mM} \mathrm{KNO}_{3}, 7.5 \mathrm{mM}$ $\mathrm{Ca}\left(\mathrm{NO}_{3}\right)_{2} \cdot 4 \mathrm{H}_{2} \mathrm{O}, 3.25 \mathrm{mM} \mathrm{NH} \mathrm{H}_{2} \mathrm{PO}_{4}, 1.5 \mathrm{mM} \mathrm{MgSO} \cdot \cdot 7$ $\mathrm{H}_{2} \mathrm{O}, 62.50 \mu \mathrm{M} \mathrm{KCl}, 31.25 \mu \mathrm{M} \mathrm{H}_{3} \mathrm{BO}_{3}, 2.50 \mu \mathrm{M} \mathrm{MnSO}_{4}$. $\mathrm{H}_{2} \mathrm{O}, 2.50 \mu \mathrm{M} \mathrm{ZnSO} \cdot 7 \mathrm{H}_{2} \mathrm{O}, 0.63 \mu \mathrm{M} \mathrm{CuSO}_{4} \cdot 5 \mathrm{H}_{2} \mathrm{O}$, $0.63 \mu \mathrm{M} \mathrm{NaMoO} \cdot 5 \mathrm{H}_{2} \mathrm{O}$ and $250.0 \mu \mathrm{M} \mathrm{NaEDTAFe} \cdot 3 \mathrm{H}_{2} \mathrm{O}$. To simulate $\mathrm{Ni}^{2+}$ toxicity, $\mathrm{NiCl}_{2}$ was used at concentrations of 0 and $600 \mathrm{mM} \mathrm{Ni}$, which was applied over 15 days (days 70 85 after the start of the experiment). Nutrient solutions were changed at 07:00 $\mathrm{h}$ at 3-day intervals, with $\mathrm{pH}$ adjusted to 5.5.

\subsection{Measurement of chlorophyll fluorescence and gas exchange}

Chlorophyll fluorescence was measured using a modulated chlorophyll fluorometer (model OS5p; Opti-Sciences) in fully 
expanded leaves under light. Preliminary tests determined the location of the leaf, the part of the leaf and the time required to obtain the greatest $\mathrm{Fv} / \mathrm{Fm}$ ratio; therefore, the acropetal third of leaves that were in the middle third of the plant and adapted to the dark for $30 \mathrm{~min}$ was used in the evaluation. The intensity and duration of the saturation light pulse were $7500 \mu \mathrm{mol} \mathrm{m}^{-2} \mathrm{~s}^{-1}$ and $0.7 \mathrm{~s}$, respectively. The gas exchange was evaluated using an infrared gas analyser (model LCPro+; ADC BioScientific) in all plants under constant conditions of $\mathrm{CO}_{2}$ concentration, photosynthetically active radiation, airflow rate and temperature in a chamber at $360 \mu \mathrm{mol} \mathrm{mol}^{-1}$ $\mathrm{CO}_{2}, 800 \mu \mathrm{mol}$ photons $\mathrm{m}^{-2} \mathrm{~s}^{-1}, 300 \mu \mathrm{mol} \mathrm{s}^{-1}$ and $28{ }^{\circ} \mathrm{C}$, respectively, between 10:00 and 12:00 $\mathrm{h}$.

\subsection{Leaf and root anatomy}

Samples were collected from the middle region of the leaf limb of fully expanded leaves and roots $5 \mathrm{~cm}$ from the root apex, being used five samples. All botanical material was fixed in FAA 70 for $24 \mathrm{~h}$, dehydrated in ethanol and embedded in historesin Leica ${ }^{\mathrm{TM}}$ (Leica, Nussloch, Germany). Transverse sections with a thickness of $5 \mu \mathrm{m}$ were obtained with a rotating microtome (model Leica RM 2245, Leica Biosystems) and were stained with toluidine blue (O'Brien et al. 1964). For stomatal characterization, the epidermal impression method was used according to Segatto et al. (2004). The slides were observed and photomicrographed under an optical microscope (Motic BA 310, Motic Group Co. LTD.) coupled to a digital camera (Motic 2500, Motic Group Co., LTD.). The images were analysed with Motic plus 2.0, which was previously calibrated with a micrometre slide supplied by the manufacturer.

\subsection{Determining of Ni and nutrients}

Samples with $100 \mathrm{mg}$ of milled samples were weighed in 50-mL conical tubes (Falcon ${ }^{\mathrm{R}}$, Corning, Mexico) and predigested (48 h) with $2 \mathrm{ml}$ of sub boiled $\mathrm{HNO}_{3}$ (DST 1000, Savillex, USA). After, $8 \mathrm{ml}$ of a solution containing $4 \mathrm{ml}$ of $\mathrm{H}_{2} \mathrm{O}_{2}(30 \% \mathrm{v} / \mathrm{v}$, Synth, Brasil) and $4 \mathrm{ml}$ of ultra-pure water (Milli-Q System, Millipore, USA) were added, and the mixture was transferred to a Teflon digestion vessel, closed and heated in a block digester (EasyDigest ${ }^{\circledR}$, Analab, France). The determinations of Ni, P, Ca, S, B, Mn and Mo were carried out using an inductively coupled plasma mass spectrometer (ICP-MS 7900, Agilent, USA).

\subsection{Extraction of antioxidant enzymes, superoxide and soluble proteins}

Antioxidant enzymes (SOD, CAT, APX and POX), superoxide and soluble proteins were extracted from leaf tissues according to the method of Badawi et al. (2004). Quantification of the total soluble proteins was performed using the method described by (Bradford 1976). Absorbance was measured at $595 \mathrm{~nm}$, using bovine albumin as a standard. SOD assay (EC 1.15.1.1) was measured at $560 \mathrm{~nm}$ (Giannopolitis and Ries 1977).One SOD unit was defined as the amount of enzyme required to inhibit $50 \%$ of the NBT photoreduction. The SOD activity was expressed in unit $\mathrm{mg}^{-1}$ protein. CAT assay (EC 1.11.1.6) was measured at $240 \mathrm{~nm}$ (Havir and McHale 1987). The CAT activity was expressed in $\mu \mathrm{mol} \mathrm{H}_{2} \mathrm{O}_{2} \mathrm{mg}^{-1}$ protein $\min ^{-1}$. APX assay (EC 1.11.1.11) was measured at $290 \mathrm{~nm}$ (Nakano and Asada 1981). The APX activity was expressed in $\mu \mathrm{mol}$ AsA mg ${ }^{-1}$ protein $\mathrm{min}^{-1}$. POX assay (EC 1.11.1.7 measured at $470 \mathrm{~nm}$ (Cakmak and Marschner 1992). The POX activity was expressed in $\mu \mathrm{mol}$ tetraguaiacol $\mathrm{mg}^{-1}$ protein $\min ^{-1}$.

\subsection{Determination of superoxide concentration}

To determine $\mathrm{O}_{2}{ }^{-}, 1 \mathrm{ml}$ of extract was incubated with $30 \mathrm{mM}$ phosphate buffer [pH 7.6] and $0.51 \mathrm{mM}$ hydroxylamine hydrochloride for $20 \mathrm{~min}$ at $25^{\circ} \mathrm{C}$. Then, $17 \mathrm{mM}$ sulphanilamide and $7 \mathrm{mM} \alpha$-naphthylamine were added to the incubation mixture for $20 \mathrm{~min}$ at $25^{\circ} \mathrm{C}$. After the reaction, ethyl ether was added in the identical volume and centrifuged at $3000 \times g$ for $5 \mathrm{~min}$. The absorbance was measured at $530 \mathrm{~nm}$ (Elstner and Heupel 1976).

\subsection{Extraction of nonenzymatic compounds}

Nonenzymatic compounds $\left(\mathrm{H}_{2} \mathrm{O}_{2}\right.$ and MDA) were extracted as described by Wu et al. (2006). Briefly, a mixture for extraction of $\mathrm{H}_{2} \mathrm{O}_{2}$ and MDA was prepared by homogenizing $500 \mathrm{mg}$ of fresh leaf materials in $5 \mathrm{~mL}$ of $5 \%(\mathrm{w} / \mathrm{v})$ trichloroacetic acid. To measure, $\mathrm{H}_{2} \mathrm{O}_{2}$ was measured at $390 \mathrm{~nm}$ (Velikova et al. 2000). MDA was determined by the method of Cakmak and Horst (1991), with minor modifications and using an extinction coefficient of $155 \mathrm{mM}^{-1} \mathrm{~cm}^{-1}$.

\subsection{Determination of electrolyte leakage and photosynthetic pigments}

Electrolyte leakage was measured according to the method of Gong et al. (1998) with minor modifications. Pigments were quantified using a spectrophotometer (model UV-M51; Bel Photonics), according to the methodology of Lichtenthaler and Buschmann (2001).

\subsection{Measurements of biomass}

The biomass of root, stem and leaf was measured based on constant dry weight (g), after drying in a forced-air ventilation oven at $65^{\circ} \mathrm{C}$. 


\subsection{Data analysis}

The data (Ribeiro et al. 2019) had the homogeneity of variances tested and subsequently were submitted to one-way ANOVA and applied Scott-Knott test at a probability level of 5\% (Steel et al. 2006). All statistical procedures used the Assistat 7.7 software.

\section{Results}

\subsection{EBR reduced the Ni content and positively modulated the root anatomy}

$\mathrm{Ni}^{2+}$ treatment promoted a significant increase in $\mathrm{Ni}$ content in all tissues of E. urophylla (Table 1). Plants exposed to $\mathrm{Ni}^{2+}$ and EBR presented smaller Ni contents in leaf, stem and root. Plants subjected to $\mathrm{Ni}^{2+}$ toxicity. Plants subjected to $\mathrm{Ni}^{2+}$ toxicity displayed largely changed root anatomy (Fig. 1). However, the application of $100 \mathrm{nM}$ of EBR in plants subjected to $600 \mu \mathrm{M}$ of $\mathrm{Ni}^{2+}$ promoted increases in RET, RDT, RCT, VCD and RMD, comparison with similar treatment without EBR (Table 2).

\subsection{EBR increased the nutrient content and induced ionic homeostasis in plants treated with $\mathrm{Ni}$}

$\mathrm{Ni}^{2+}$ resulted in smaller contents of all nutrients in root, stem and leaf tissues (Table 3), compared with control plants. However, plants treated with $\mathrm{Ni}^{2+}$ and EBR displayed higher levels of P, Ca, S, B, Mn and Mo in root, stem and leaf, when compared to the same treatment without EBR. Treatment in the absence of $\mathrm{Ni}^{2+}$ and spraying with EBR also showed increases in $\mathrm{P}, \mathrm{Ca}, \mathrm{S}, \mathrm{B}, \mathrm{Mn}$ and Mo in all tissues evaluated, compared to treatment under absence $\mathrm{Ni}^{2+}$ and without EBR. On ionic ratios, plants exposed to $\mathrm{Ni}^{2+}$ and sprayed with EBR had increases in $\mathrm{Ca}^{2+} / \mathrm{Ni}^{2+}$ and $\mathrm{Mn}^{2+} / \mathrm{Ni}^{2+}$ ratios in root, stem and leaf (Table 4), compared with equal treatment without EBR.

\subsection{Foliar spray increased the levels of photosynthetic} pigments

$\mathrm{Ni}^{2+}$ toxicity caused a decrease in the levels of photosynthetic pigments (Table 5 ). The plants exposed to $\mathrm{Ni}^{2+}$ and EBR showed increases in $\mathrm{Chl} a, \mathrm{Chl} b$, Car and $\mathrm{Chl}$ total, respectively, and reductions in $\mathrm{Chl} a / \mathrm{Chl} b$ and $\mathrm{Chl}$ total/Car, when compared to the same treatment without EBR.

\subsection{Steroids enhanced the photon capture efficiency}

Plants exposed to $\mathrm{Ni}^{2+}$ toxicity suffered negative interferences for chlorophyll fluorescence (Fig. 2). However, plants treated with $\mathrm{Ni}^{2+}$ and EBR had decreases in $\mathrm{F}_{0}$ and $\mathrm{F}_{\mathrm{m}}$, as well as increases in $F_{v}$ and $F_{v} / F_{m}$, compared to the same treatment without EBR. Plants treated with $\mathrm{Ni}^{2+}$ and EBR presented increases in the values of $\Phi_{\text {PSII }}, q_{p}$ and ETR (Table 5) and reductions in NPQ, EXC and ETR $/ P_{\mathrm{N}}$, compared to the same treatment without EBR.

\subsection{Mitigation of the $\mathrm{Ni}^{2+}$ effects on gas exchange}

$\mathrm{Ni}^{2+}$ caused negative repercussions for the gas exchange (Table 5). Spraying EBR on plants suffering from $\mathrm{Ni}^{2+}$ toxicity resulted in increases in the values of $P_{\mathrm{N}}, E, g_{\mathrm{s}}$, WUE and $P_{\mathrm{N}} / C_{\mathrm{i}}$; however, there was a reduction in $C_{\mathrm{i}}$, when compared to plants exposed to $\mathrm{Ni}^{2+}$ toxicity without EBR.

\subsection{Steroid improved density and functionality of stomatal in plants suffering from Ni toxicity}

The $\mathrm{Ni}^{2+}$ induced negative effects on stomatal characteristics (Table 6). On the adaxial side, plants exposed to $\mathrm{Ni}^{2+}$ and EBR had increases in SD, SF and SI and reductions in PDS and $11 \%$ EDS. In the abaxial face, the EBR increased SD, SF and SI variables, and reduced the PDS and EDS, when compared to the same treatment without EBR.
Table 1 Ni contents in young Eucalyptus urophylla plants sprayed with EBR and exposed to Ni toxicity

\begin{tabular}{|c|c|c|c|c|c|c|c|}
\hline \multirow{2}{*}{$\frac{\mathrm{Ni}}{-}$} & \multirow{2}{*}{$\begin{array}{l}\text { EBR } \\
-\end{array}$} & \multicolumn{2}{|c|}{$\mathrm{Ni}$ in $\operatorname{root}\left(\mu \mathrm{g} \mathrm{g} \mathrm{DM}^{-1}\right)$} & \multicolumn{2}{|c|}{$\mathrm{Ni}$ in stem $\left(\mu \mathrm{g} \mathrm{g} \mathrm{DM}^{-1}\right)$} & \multicolumn{2}{|c|}{$\mathrm{Ni}$ in leaf $\left(\mu \mathrm{g} \mathrm{g} \mathrm{DM}^{-1}\right)$} \\
\hline & & $1.68 \mathrm{c}$ & & $0.17 \mathrm{c}$ & & $0.05 \mathrm{c}$ & \\
\hline- & + & $1.65 \mathrm{c}$ & $-2 \%$ & $0.16 \mathrm{c}$ & $-6 \%$ & $0.04 \mathrm{c}$ & $-20 \%$ \\
\hline+ & - & $343.07 \mathrm{a}$ & & $32.87 \mathrm{a}$ & & $51.00 \mathrm{a}$ & \\
\hline+ & + & $232.35 b$ & $-32 \%$ & $24.86 \mathrm{~b}$ & $-24 \%$ & $46.29 \mathrm{~b}$ & $-9 \%$ \\
\hline
\end{tabular}

$\mathrm{Ni}=$ Nickel. Comparison with similar treatment without EBR. Columns with different letters indicate significant differences from the Scott-Knott test $(P<0.05)$. Values described corresponding to means from five repetitions and standard deviations 
Fig. 1 Root cross sections in young Eucalyptus urophylla plants sprayed with EBR and exposed to Ni toxicity. $-\mathrm{Ni}^{2+} /-$ $\operatorname{EBR}(\mathbf{A}),-\mathrm{Ni}^{2+} /+\operatorname{EBR}(\mathbf{B}),+$ $\mathrm{Ni}^{2+} /-\mathrm{EBR}(\mathbf{C})$, and $+\mathrm{Ni}^{2+} /+$ EBR (D). Legends: $\mathrm{RE}=$ Root epidermis; $\mathrm{RC}=$ Root cortex; $\mathrm{RD}=$ Root endodermis; $\mathrm{VC}=$ Vascular cylinder; $\mathrm{RM}=$ Root metaxylem. Bars $300 \mu \mathrm{m}$

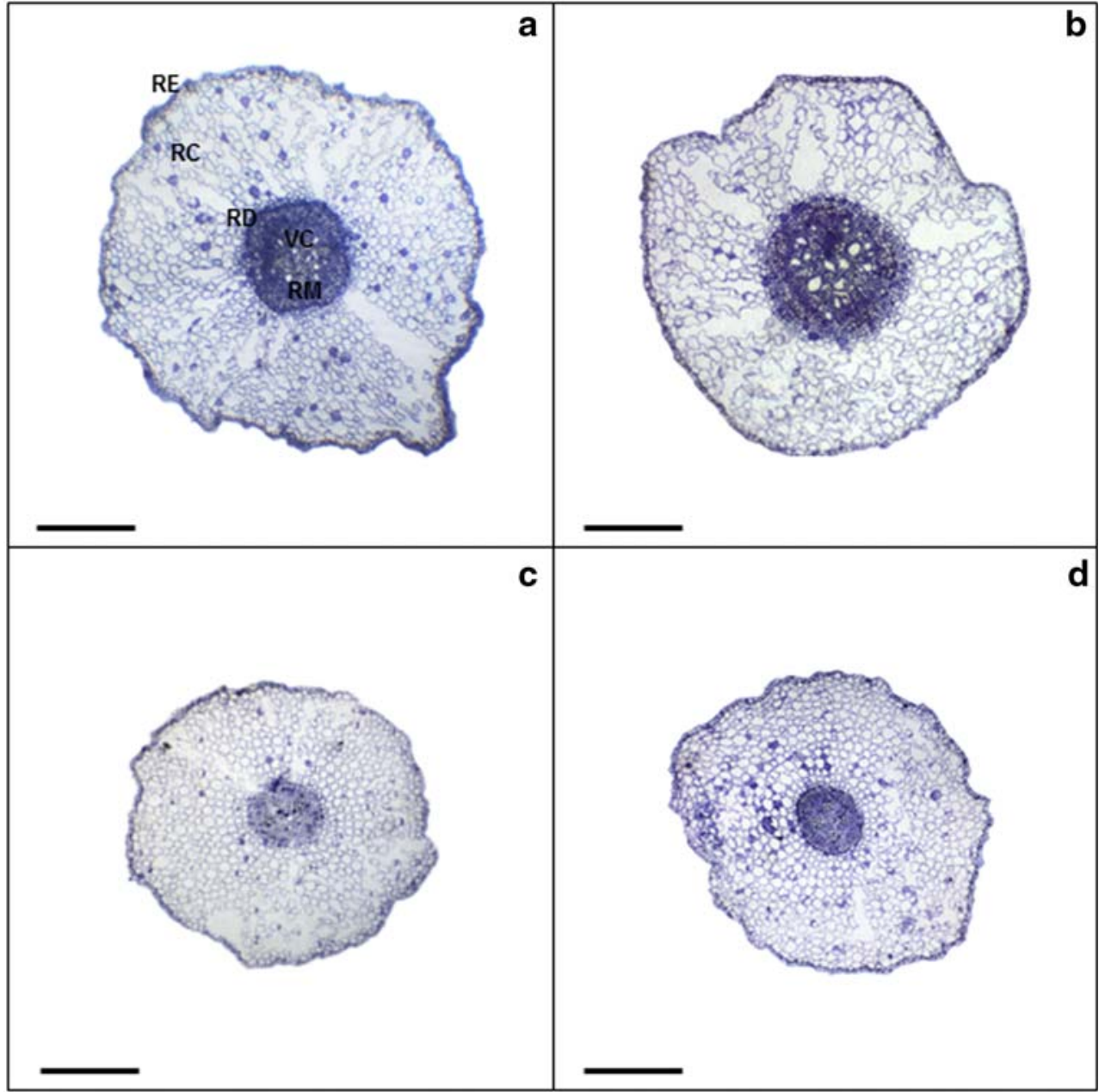

\subsection{Negative impacts on leaf anatomy were mitigated in plants sprayed with EBR}

Plants exposed to $\mathrm{Ni}^{2+}$ had reductions on leaf anatomical variables (Fig. 3). However, plants treated with the combined effects of $\mathrm{Ni}^{2+}$ and EBR showed increases in the values of ETAd, ETAb, PPT and SPT (Table 6), and a reduction in the $\mathrm{PPT} / \mathrm{SPT}$, when compared to the same treatments without EBR. Plants not treated with $\mathrm{Ni}^{2+}$ and sprayed with EBR also had increases in ETAd, ETAb, PPT and SPT, and a reduction in PPT/SPT, if compared to the control treatment of $0 \mu \mathrm{M} \mathrm{Ni}^{2+}$ and $0 \mathrm{nM}$ EBR.

\subsection{Beneficial actions of EBR on the antioxidant system}

The $\mathrm{Ni}^{2+}$ concentration in the solution applied to plants provoked increases in the activities of the antioxidant enzymes (Fig. 4). Plants responding to the combined effects of $\mathrm{Ni}^{2+}$ and
Table 2 Root anatomy in young Eucalyptus urophylla plants sprayed with EBR and exposed to Ni toxicity

\begin{tabular}{|c|c|c|c|c|c|c|c|c|c|c|c|}
\hline $\mathrm{Ni}$ & EBR & \multicolumn{2}{|c|}{$\operatorname{RET}(\mu \mathrm{m})$} & \multicolumn{2}{|c|}{ RDT $(\mu \mathrm{m})$} & \multicolumn{2}{|c|}{$\mathrm{RCT}(\mu \mathrm{m})$} & \multicolumn{2}{|c|}{$\mathrm{VCD}(\mu \mathrm{m})$} & \multicolumn{2}{|c|}{$\mathrm{RMD}(\mu \mathrm{m})$} \\
\hline- & - & $15.0 \mathrm{a}$ & & $11.6 \mathrm{a}$ & & 411a & & $228 b$ & & $13.0 \mathrm{a}$ & \\
\hline- & + & $15.6 \mathrm{a}$ & $4 \%$ & $12.1 \mathrm{a}$ & $4 \%$ & $417 \mathrm{a}$ & $1 \%$ & $249 \mathrm{a}$ & $9 \%$ & $13.5 \mathrm{a}$ & $4 \%$ \\
\hline+ & - & $6.5 \mathrm{c}$ & & $6.1 \mathrm{c}$ & & $336 b$ & & $199 \mathrm{c}$ & & $9.3 \mathrm{c}$ & \\
\hline+ & + & $9.8 \mathrm{~b}$ & $51 \%$ & $8.8 \mathrm{~b}$ & $44 \%$ & $353 b$ & $5 \%$ & $222 b$ & $12 \%$ & $10.9 b$ & $17 \%$ \\
\hline
\end{tabular}

RET $=$ Root epidermis thickness RDT $=$ Root endodermis thickness RCT $=$ Root cortex thickness VCD = Vascular cylinder diameter; RMD = Root metaxylem diameter. Comparison with similar treatment without EBR. Columns with different letters indicate significant differences from the Scott-Knott test $(P<0.05)$. Values described corresponding to means from five repetitions and standard deviations 
Table 3 Nutrient contents in young Eucalyptus urophylla plants sprayed with EBR and exposed to Ni toxicity

\begin{tabular}{|c|c|c|c|c|c|c|c|c|c|c|c|c|c|}
\hline \multirow{2}{*}{\multicolumn{2}{|c|}{$\begin{array}{l}\mathrm{Ni} \text { EBR } \\
\text { Contents in } \mathrm{r}\end{array}$}} & \multicolumn{2}{|c|}{$\mathrm{P}\left(\mathrm{mg} \mathrm{g} \mathrm{DM}^{-1}\right)$} & \multicolumn{2}{|c|}{$\mathrm{Ca}\left(\mathrm{mg} \mathrm{g} \mathrm{DM}^{-1}\right)$} & \multicolumn{2}{|c|}{$\mathrm{S}\left(\mathrm{mg} \mathrm{g} \mathrm{DM}{ }^{-1}\right)$} & \multicolumn{2}{|c|}{$\mathrm{B}\left(\mu \mathrm{g} \mathrm{g} \mathrm{DM}^{-1}\right)$} & \multicolumn{2}{|c|}{$\mathrm{Mn}\left(\mu \mathrm{g} \mathrm{g} \mathrm{DM}^{-1}\right)$} & \multicolumn{2}{|c|}{ Mo $\left(\mu \mathrm{g} \mathrm{g} \mathrm{DM}^{-1}\right)$} \\
\hline & & & & & & & & & & & & & \\
\hline- & - & $8.36 \mathrm{~b}$ & & $9.41 \mathrm{~b}$ & & $3.79 b$ & & $75.59 \mathrm{a}$ & & $40.00 \mathrm{~b}$ & & $35.62 \mathrm{a}$ & \\
\hline- & + & $9.39 \mathrm{a}$ & $12 \%$ & $11.85 \mathrm{a}$ & $26 \%$ & $4.32 \mathrm{a}$ & $14 \%$ & $78.11 \mathrm{a}$ & $3 \%$ & $44.87 \mathrm{a}$ & $12 \%$ & $36.74 a$ & $3 \%$ \\
\hline+ & - & $4.39 \mathrm{~d}$ & & $6.69 \mathrm{~d}$ & & $3.02 \mathrm{c}$ & & $55.88 \mathrm{c}$ & & $33.65 \mathrm{~d}$ & & $20.52 \mathrm{c}$ & \\
\hline+ & + & $5.24 \mathrm{c}$ & $19 \%$ & $7.45 \mathrm{c}$ & $11 \%$ & $3.28 \mathrm{c}$ & $9 \%$ & $64.82 \mathrm{~b}$ & $16 \%$ & $36.23 \mathrm{c}$ & $8 \%$ & $24.57 b$ & $20 \%$ \\
\hline \multicolumn{14}{|c|}{ Contents in stem } \\
\hline- & - & $3.25 \mathrm{a}$ & & $6.25 \mathrm{a}$ & & $1.62 \mathrm{a}$ & & $74.71 \mathrm{a}$ & & $25.86 \mathrm{a}$ & & $1.28 \mathrm{a}$ & \\
\hline- & + & $3.50 \mathrm{a}$ & $8 \%$ & $6.40 \mathrm{a}$ & $2 \%$ & $1.66 \mathrm{a}$ & $2 \%$ & $79.38 \mathrm{a}$ & $6 \%$ & $27.73 a$ & $7 \%$ & $1.32 \mathrm{a}$ & $3 \%$ \\
\hline+ & - & $3.25 \mathrm{a}$ & & $5.74^{\mathrm{a}}$ & & $1.38 \mathrm{~b}$ & & $66.03 b$ & & $10.93 \mathrm{c}$ & & $0.48 b$ & \\
\hline+ & + & $3.26 \mathrm{a}$ & $0 \%$ & $5.81 \mathrm{a}$ & $1 \%$ & $1.43 \mathrm{~b}$ & $4 \%$ & $67.88 \mathrm{~b}$ & $3 \%$ & $13.94 \mathrm{~b}$ & $28 \%$ & $0.50 \mathrm{~b}$ & $4 \%$ \\
\hline \multicolumn{14}{|c|}{ Contents in leaf } \\
\hline- & - & $3.76 \mathrm{a}$ & & $8.35 \mathrm{a}$ & & $3.15 \mathrm{a}$ & & $91.44 \mathrm{a}$ & & $56.51 \mathrm{~b}$ & & $4.09 \mathrm{a}$ & \\
\hline- & + & $3.81 \mathrm{a}$ & $1 \%$ & $8.38 \mathrm{a}$ & $0 \%$ & $3.32 \mathrm{a}$ & $5 \%$ & $98.06 \mathrm{a}$ & $7 \%$ & $58.59 \mathrm{a}$ & $4 \%$ & $4.21 \mathrm{a}$ & $3 \%$ \\
\hline+ & - & $3.10 \mathrm{c}$ & & $7.21 \mathrm{c}$ & & $2.74 b$ & & $77.32 \mathrm{~b}$ & & $50.25 \mathrm{c}$ & & $2.88 \mathrm{c}$ & \\
\hline+ & + & $3.41 \mathrm{~b}$ & $10 \%$ & $7.74 b$ & $7 \%$ & $2.84 \mathrm{~b}$ & $4 \%$ & $92.89 \mathrm{a}$ & $20 \%$ & $52.25 \mathrm{c}$ & $4 \%$ & $3.75 \mathrm{~b}$ & $30 \%$ \\
\hline
\end{tabular}

$\mathrm{P}=$ Phosphorus; $\mathrm{Ca}=$ Calcium; $\mathrm{S}=$ Sulphur; $\mathrm{B}=$ Boron; $\mathrm{Mn}=$ Manganese; $\mathrm{Mo}=$ Molybdenum. Comparison with similar treatment without EBR . Columns with different letters indicate significant differences from the Scott-Knott test $(P<0.05)$. Values described corresponding to means from five repetitions and standard deviations

EBR showed increases in SOD, CAT, APX and POX, compared to the same treatment without EBR.

\subsection{EBR reduced the oxidative stress induced by $\mathrm{Ni}$ toxicity}

Plants exposed to $\mathrm{Ni}^{2+}$ toxicity showed negative effects on oxidant compounds (Fig. 5). Plants exposed to $\mathrm{Ni}^{2+}$ and sprayed with EBR had reductions in the values of $\mathrm{O}_{2}{ }^{-}$, $\mathrm{H}_{2} \mathrm{O}_{2}$ and EL, compared to the same treatment without EBR.

Table 4 Ionic ratios in young Eucalyptus urophylla plants sprayed with EBR and exposed to Ni toxicity

\begin{tabular}{llllllll}
\hline $\mathrm{Ni}^{2+}$ & EBR & Root & & \multicolumn{2}{l}{ Stem } & \multicolumn{2}{l}{ Leaf } \\
\hline $\mathrm{Ca}^{2+} / \mathrm{Ni}^{2+}$ ratio & & & & & & \\
- & - & $5.65 \mathrm{~b}$ & & $36.86 \mathrm{~b}$ & & $172.48 \mathrm{~b}$ & \\
- & + & $7.23 \mathrm{a}$ & $28 \%$ & $40.01 \mathrm{a}$ & $9 \%$ & $198.39 \mathrm{a}$ & $15 \%$ \\
+ & - & $0.02 \mathrm{c}$ & & $0.14 \mathrm{~d}$ & & $0.13 \mathrm{~d}$ & \\
+ & + & $0.03 \mathrm{c}$ & $50 \%$ & $19 \mathrm{c}$ & $36 \%$ & $0.18 \mathrm{c}$ & $38 \%$ \\
$\mathrm{Mn}^{2+} / \mathrm{Ni}^{2+}$ ratio & & & & & & \\
- & - & $24.01 \mathrm{~b}$ & & $152.84 \mathrm{~b}$ & & $1166.96 \mathrm{~b}$ & \\
- & + & $27.40 \mathrm{a}$ & $14 \%$ & $173.36 \mathrm{a}$ & $13 \%$ & $1387.43 \mathrm{a}$ & $19 \%$ \\
+ & - & $0.07 \mathrm{~d}$ & & $0.33 \mathrm{~d}$ & & $0.98 \mathrm{~d}$ & \\
+ & + & $0.10 \mathrm{c}$ & $43 \%$ & $0.46 \mathrm{c}$ & $39 \%$ & $1.13 \mathrm{c}$ & $15 \%$ \\
\hline
\end{tabular}

$\mathrm{Ca}^{2+} / \mathrm{Ni}^{2+}=$ Calcium and nickel ratio; $\mathrm{Mn}^{2+} / \mathrm{Ni}^{2+}=$ Manganese and nickel ratio. Comparison with similar treatment without EBR. Columns with different letters indicate significant differences from the Scott-Knott test $(P<0.05)$. Values described corresponding to means from five repetitions and standard deviations

\subsection{Mitigation of the toxic effects of $\mathrm{Ni}^{2+}$ promoted by EBR on biomass}

The stress caused by the $\mathrm{Ni}^{2+}$ toxicity resulted in significant decreases in variables related to growth (Fig. 6). Spraying plants suffering from $\mathrm{Ni}^{2+}$ toxicity with EBR promoted increases in the values of LDM, RDM, SDM and TDM, compared to the same treatment without EBR.

\section{Discussion}

The increases observed in $\mathrm{Ni}^{2+}$ contents in the root, stem and leaf of young Eucalyptus urophylla plants confirm the absorption and accumulation of $\mathrm{Ni}$ in tissues of treated plants. On the other hand, plants exposed to EBR presented reductions in $\mathrm{Ni}^{2+}$, in relation to equal treatment without steroid, being verified reductions more intense in leaf tissue. $\mathrm{Ni}^{2+}$ in high concentrations can inhibit ZIP/NRAMP transporters linked to uptake of other elements vital to the physiological processes, mainly with $\mathrm{Ca}, \mathrm{Mg}, \mathrm{Fe}$ and $\mathrm{Zn}$ (Mizuno et al. 2005; Ahmad et al. 2007; Deng et al. 2016). Sharma et al. (2011) described the positive effects of EBR on Raphanus sativus seedlings cultivated under $\mathrm{Ni}^{2+}$ stress, being detected as improvements linked to root length and a higher efficiency of the antioxidant system in the shoot. Sellami et al. (2012) investigating the effect of $\mathrm{Ni}^{2+}$ hyperaccumulation on the physiological characteristics of Alyssum murale when cultivated in soil mixed with sewage sludge observed significant increases of $\mathrm{Ni}^{2+}$ in the tissues of roots, stems and leaves. Similar to behaviour found 
Table 5 Photosynthetic pigments, chlorophyll fluorescence and gas exchange in young Eucalyptus urophylla plants sprayed with EBR and exposed to Ni toxicity

Photosynthetic pigments

\begin{tabular}{|c|c|c|c|c|c|c|c|c|c|c|c|c|c|}
\hline \multirow{2}{*}{$\begin{array}{l}\mathrm{Ni} \\
-\end{array}$} & \multirow{2}{*}{$\begin{array}{c}\text { EBR } \\
-\end{array}$} & \multicolumn{2}{|c|}{$\begin{array}{l}\text { Chl } a\left(\mathrm{mg} \mathrm{g}^{-1}\right. \\
\text { FM) }\end{array}$} & \multicolumn{2}{|l|}{$\mathrm{Chl} b\left(\mathrm{mg} \mathrm{g}^{-1} \mathrm{FM}\right)$} & \multicolumn{2}{|c|}{$\begin{array}{l}\text { Total Chl } \\
\left(\mathrm{mg} \mathrm{g}^{-1} \mathrm{FM}\right)\end{array}$} & \multicolumn{2}{|l|}{$\mathrm{Car}\left(\mathrm{mg} \mathrm{g}^{-1} \mathrm{FM}\right)$} & \multicolumn{2}{|c|}{ Ratio Chl $a / \mathrm{Chl} b$} & \multicolumn{2}{|c|}{ Ratio total Chl/Car } \\
\hline & & $9.46 b$ & & $3.98 \mathrm{~b}$ & & $13.44 b$ & & $0.67 \mathrm{~b}$ & & $2.39 \mathrm{c}$ & & $19.9 b$ & \\
\hline- & + & $10.96 \mathrm{a}$ & $16 \%$ & $4.66 \mathrm{a}$ & $17 \%$ & $15.63 \mathrm{a}$ & $16 \%$ & $0.82 \mathrm{a}$ & $22 \%$ & $2.36 \mathrm{c}$ & $-1 \%$ & $19.2 \mathrm{~b}$ & $-4 \%$ \\
\hline+ & - & $7.76 \mathrm{c}$ & & $2.49 \mathrm{~d}$ & & $10.25 \mathrm{~d}$ & & $0.45 \mathrm{~d}$ & & $3.13 \mathrm{a}$ & & $22.6 \mathrm{a}$ & \\
\hline+ & + & $8.86 \mathrm{~b}$ & $14 \%$ & $3.17 \mathrm{c}$ & $27 \%$ & $12.03 \mathrm{c}$ & $17 \%$ & $0.59 \mathrm{c}$ & $31 \%$ & $2.80 \mathrm{~b}$ & $-11 \%$ & $20.4 b$ & $-10 \%$ \\
\hline \multicolumn{14}{|c|}{ Chlorophyll fluorescence } \\
\hline $\mathrm{Ni}$ & EBR & $\Phi_{\mathrm{PSII}}$ & & $\mathrm{q}_{\mathrm{P}}$ & & NPQ & & $\operatorname{ETR}\left(\mu \mathrm{mol} \mathrm{m}{ }^{-2} \mathrm{~s}^{-1}\right)$ & & $\begin{array}{l}\text { EXC } \\
\qquad \underset{\left.s^{-1}\right)}{(\mu \mathrm{m}}\end{array}$ & $\mathrm{m}^{-2}$ & $\mathrm{ETR} / P_{\mathrm{N}}$ & \\
\hline- & - & $0.31 \mathrm{a}$ & & $0.84 \mathrm{a}$ & & $0.72 \mathrm{c}$ & & $45.48 \mathrm{a}$ & & $0.62 \mathrm{c}$ & & $2.44 a$ & \\
\hline- & + & $0.32 \mathrm{a}$ & $3 \%$ & $0.80 \mathrm{a}$ & $-5 \%$ & $0.69 \mathrm{c}$ & $-4 \%$ & $47.08 \mathrm{a}$ & $4 \%$ & $0.62 \mathrm{c}$ & $0 \%$ & $2.44 \mathrm{a}$ & $0 \%$ \\
\hline+ & - & $0.16 \mathrm{c}$ & & $0.51 \mathrm{~b}$ & & $1.12 \mathrm{a}$ & & $23.97 \mathrm{c}$ & & $0.77 \mathrm{a}$ & & $2.60 \mathrm{a}$ & \\
\hline+ & + & $0.23 b$ & $44 \%$ & $0.53 b$ & $4 \%$ & $0.99 \mathrm{~b}$ & $-12 \%$ & $34.08 b$ & $42 \%$ & $0.71 b$ & $-8 \%$ & $2.54 \mathrm{a}$ & $-2 \%$ \\
\hline \multicolumn{14}{|c|}{ Gas exchange } \\
\hline $\mathrm{Ni}$ & EBR & $\begin{array}{l}P_{\mathrm{N}} \\
\qquad \underset{\left.\mathrm{s}^{-1}\right)}{(\mu \mathrm{mol}}\end{array}$ & $\mathrm{m}^{-2}$ & $E\left(\mathrm{mmol} \mathrm{m} \mathrm{m}^{-2} \mathrm{~s}^{-1}\right)$ & & $g_{\mathrm{s}}(\mathrm{mol}$ & $\left.\mathrm{n}^{-2} \mathrm{~s}^{-1}\right)$ & $C_{\mathrm{i}}\left(\mu \mathrm{mol} \mathrm{mol}{ }^{-1}\right)$ & & $\begin{array}{l}\text { WUE } \\
\qquad(\mu \mathrm{m} \\
\left.1^{-1}\right)\end{array}$ & mmo- & $\begin{array}{c}P_{\mathrm{N}} / C_{\mathrm{i}} \\
\quad(\mu \mathrm{mo} \\
\left.\mathrm{a}^{-1}\right)\end{array}$ & $-2 \mathrm{~s}^{-1} \mathrm{P}-$ \\
\hline- & - & $18.6 \mathrm{a}$ & & $3.32 \mathrm{a}$ & & $0.45 \mathrm{a}$ & & $269 \mathrm{c}$ & & $5.6 \mathrm{a}$ & & $0.072 \mathrm{a}$ & \\
\hline- & + & $19.3 \mathrm{a}$ & $4 \%$ & $3.37 \mathrm{a}$ & $2 \%$ & $0.45 \mathrm{a}$ & $0 \%$ & $259 \mathrm{c}$ & $-4 \%$ & $5.7 \mathrm{a}$ & $2 \%$ & $0.079 \mathrm{a}$ & $10 \%$ \\
\hline+ & - & $9.2 \mathrm{c}$ & & $2.53 \mathrm{c}$ & & $0.25 \mathrm{c}$ & & $298 \mathrm{a}$ & & $3.6 \mathrm{c}$ & & $0.034 \mathrm{c}$ & \\
\hline+ & + & $13.4 \mathrm{~b}$ & $46 \%$ & $2.85 \mathrm{~b}$ & $13 \%$ & $0.31 \mathrm{~b}$ & $24 \%$ & $286 b$ & $-4 \%$ & $4.7 b$ & $31 \%$ & $0.052 b$ & $53 \%$ \\
\hline
\end{tabular}

Chl $a=$ Chlorophyll $a$; Chl $b=$ Chlorophyll $b$; Total chl = Total chlorophyll; Car = Carotenoids; $\Phi_{\mathrm{PSII}}=$ Effective quantum yield of PSII photochemistry; $\mathrm{q}_{\mathrm{P}}=$ Photochemical quenching coefficient; $\mathrm{NPQ}=$ Nonphotochemical quenching; ETR $=$ Electron transport rate; EXC $=$ Relative energy excess at the PSII level; ETR $/ P_{\mathrm{N}}=$ Ratio between the electron transport rate and net photosynthetic rate; $P_{\mathrm{N}}=$ Net photosynthetic rate; $E=$ Transpiration rate; $g_{\mathrm{s}}=$ Stomatal conductance; $C_{\mathrm{i}}=$ Intercellular $\mathrm{CO}_{2}$ concentration; WUE = Water-use efficiency; $P_{\mathrm{N}} / C_{\mathrm{i}}=$ Carboxylation instantaneous efficiency. Comparison with similar treatment without EBR. Columns with different letters indicate significant differences from the Scott-Knott test $(P<0.05)$. Values described corresponding to means from five repetitions and standard deviations

in our study, Bazihizina et al. (2015) evaluating Psidium guajava plants subjected to high $\mathrm{Ni}$ concentrations $(300$, 1000 and $3000 \mu \mathrm{M})$ verified significant increases of $\mathrm{Ni}^{2+}$ contents in the roots and interferences on root membrane functionality, including withdrawal of plasma membrane from the cell walls and disintegration of cytoplasm.

Plants exposed to toxicity by $\mathrm{Ni}^{2+}$ showed reductions in root anatomy; however, the EBR spray positively modulated these characteristics, being verified in RET, RDT, RCD, VCD and RMD. The increases in RET, RDT and RCD suggest that EBR mitigated the $\mathrm{Ni}^{2+}$ toxicity by stimulating the growth dynamics of the root meristem through the processes of cell division and expansion in the tissues of the epidermis, endoderm and cortex (Hacham et al. 2011). The increase promoted in the values of VCD and RMD indicate that the EBR improved the uptake of water and nutrients inside the plant due to the greater permeability of the membranes (Ortega et al. 2006). Atabayeva et al. (2016) investigating the effects of $\mathrm{Cu}^{2+}$ toxicity on the leaves and roots of five varieties of Triticum aestivum reported that a concentration of $0.5 \mathrm{mM}$
$\mathrm{CuSO}_{4}$ caused reductions in RDT and VCD in all of the genotypes evaluated. Gowayed and Almaghrabi (2013) studying the metal effects on germination and anatomy of Zea mays seedlings reported reductions in RCT and RMD of $19 \%$ and $31 \%$, respectively.

EBR clearly reduced the $\mathrm{Ni}^{2+}$ uptake; increased the $\mathrm{Ca}^{2+} /$ $\mathrm{Ni}^{2+}$ and $\mathrm{Mn}^{2+} / \mathrm{Ni}^{2+}$ ratios and maximized the $\mathrm{P}, \mathrm{Ca}, \mathrm{S}, \mathrm{B}, \mathrm{Mn}$ and Mo contents; the effects were more notable in the leaf and root tissues. These results can be explained by the EBR action linked to ionic homeostasis, resulting in a higher tolerance of E. urophylla plants to Ni toxicity. The increase in Ca content is indicative of improvements in membrane integrity, affecting root elongation (Ribeiro et al. 2013; Cristancho et al. 2014). Additionally, $\mathrm{Mn}$ is a component of enzymes involved in essential processes in plant metabolism, such as respiration and photosynthesis, and is required during water molecule breakdown in PSII (Aravind and Prasad 2004; Bityutskii et al. 2014). High $\mathrm{Ni}^{2+}$ concentrations inhibit H-ATPase activity as well as affect cell membrane permeability, modifying the ionic balance in the cytoplasm and decreasing nutrient uptake 


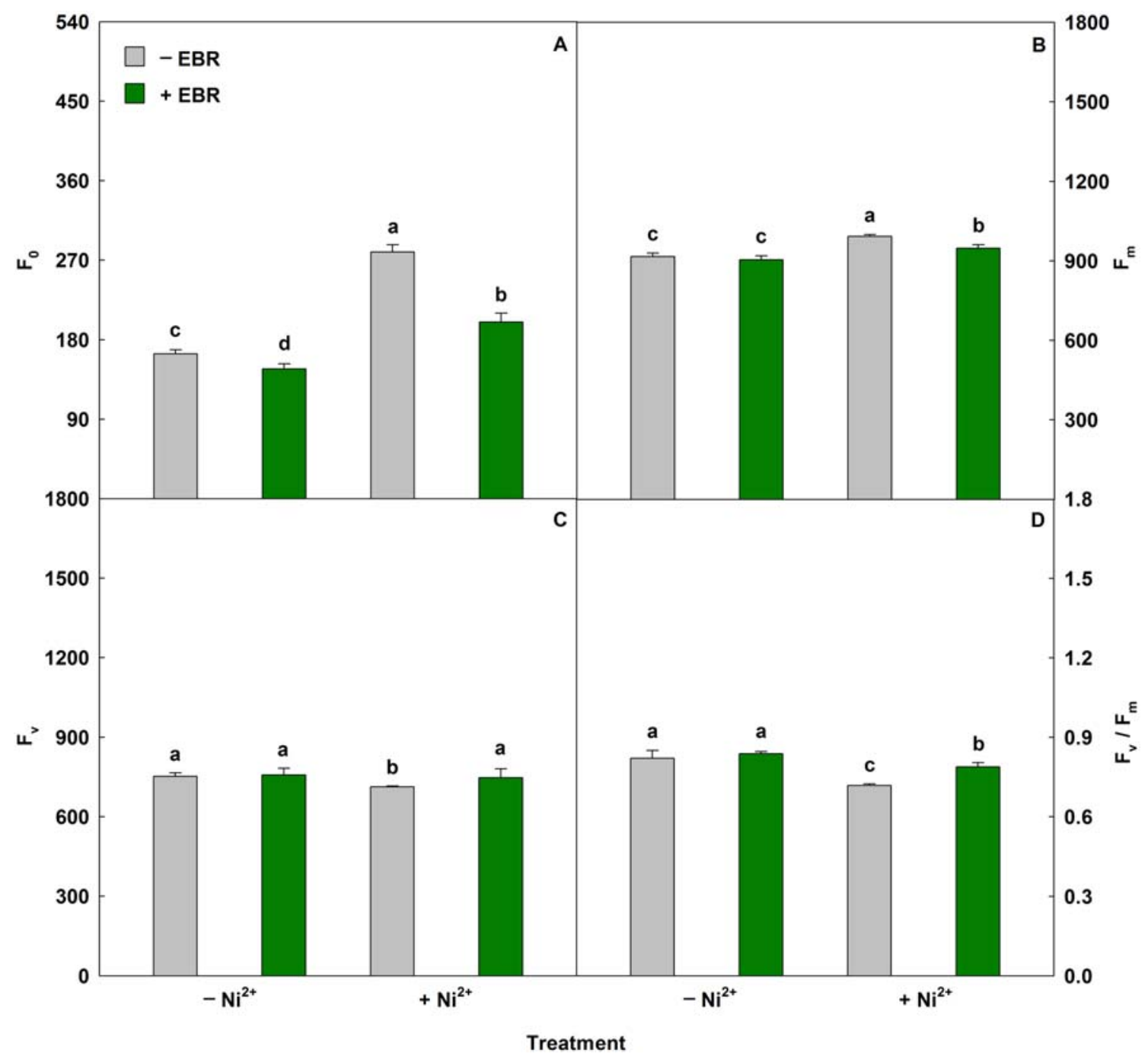

Fig. 2 Minimal fluorescence yield of the dark-adapted state $\left(\mathrm{F}_{0}\right)$, maximal fluorescence yield of the dark-adapted state $\left(\mathrm{F}_{\mathrm{m}}\right)$, variable fluorescence $\left(\mathrm{F}_{\mathrm{v}}\right)$ and maximal quantum yield of PSII photochemistry $\left(\mathrm{F}_{\mathrm{v}} / \mathrm{F}_{\mathrm{m}}\right)$ in young Eucalyptus urophylla plants sprayed with EBR and

exposed to Ni toxicity. Columns with different letters indicate significant differences from the Scott-Knott test $(P<0.05)$. Columns corresponding to means from five repetitions and standard deviations

and homeostasis (Sharma and Dhiman 2013; Sreekanth et al. 2013). Matraszek et al. (2016) studying the bioaccumulation of nutrients in Triticum aestivum plants submitted to $0.08 \mathrm{mM}$ $\mathrm{Ni}$ reported significant reductions in the contents of $\mathrm{P}, \mathrm{Ca}$ and S measured in the shoot. Rehman et al. (2016) detected reductions in $\mathrm{Mn}$ content in the roots of Zea mays under $\mathrm{Ni}^{2+}$ toxicity for 60 days. Maksimović et al. (2007) studying the effect of $\mathrm{Cd}$ and $\mathrm{Ni}$ on Zea mays seedlings detected that $\mathrm{Ni}^{2+}$ toxicity induced reductions in $\mathrm{Ca}$ and $\mathrm{Mn}$ levels in the roots by $15 \%$ and $82 \%$, respectively, when compared to the control treatment.

Foliar spray with EBR promoted increases in photosynthetic pigments (Chl $a, \mathrm{Chl} b$, Total $\mathrm{Chl}$ and Car), suggesting improvements in $\Phi_{\mathrm{PSII}}$ and consequent reactivation of electron transport, as well as chloroplast repair. The chloroplast repair was due to the decrease of ROS, as confirmed by the decrease of $\mathrm{O}_{2}{ }^{-}$and $\mathrm{H}_{2} \mathrm{O}_{2}$, which are responsible for the oxidative damage (Sharma et al. 2012; Demidchik 2015). In relation to electron transport, the $\mathrm{Chl} a, \mathrm{Chl} b$ and Car molecules are responsible for the photochemistry, absorption and transfer of solar energy to the thylakoid membranes. Thus, changes in these pigments also influence the electron transport, which in this study was detected by increases in ETR. EBR also alleviated the deficiency of $\mathrm{Mg}$ ions in the porphyrin ring of chlorophyll pigments, increasing the chlorophyll content (Sirhindi et al. 2016). Dubey and Pandey (2011) found that $\mathrm{Ni}^{2+}$ toxicity in Vigna mungo plants caused significant reductions in photosynthetic pigments. Gajewska and Skłodowska (2007) also found a decrease in chlorophyll content in Triticum aestivum plants subjected to $100 \mu \mathrm{M} \mathrm{Ni}^{2+}$.

EBR attenuated the toxic effects of $\mathrm{Ni}^{2+}$ on $\mathrm{F}_{0}, \mathrm{~F}_{\mathrm{v}}$ and $\mathrm{F}_{\mathrm{v}} /$ $\mathrm{F}_{\mathrm{m}}$, as confirmed by the decrease in $\mathrm{F}_{0}$ and the increases in $\mathrm{F}_{\mathrm{v}}$ 
Table 6 Stomatal characteristics and leaf anatomy in young Eucalyptus urophylla plants sprayed with EBR and exposed to Ni toxicity

\begin{tabular}{|c|c|c|c|c|c|c|c|c|c|c|c|}
\hline $\mathrm{Ni}$ & EBR & \multicolumn{2}{|c|}{$\begin{array}{l}\mathrm{SD} \text { (stomata per } \\
\mathrm{mm}^{2} \text { ) }\end{array}$} & \multicolumn{2}{|c|}{$\operatorname{PDS}(\mu \mathrm{m})$} & \multicolumn{2}{|c|}{$\mathrm{EDS}(\mu \mathrm{m})$} & \multicolumn{2}{|l|}{$\mathrm{SF}$} & \multicolumn{2}{|c|}{ SI $(\%)$} \\
\hline \multicolumn{12}{|c|}{ Adaxial face } \\
\hline- & - & $221 \mathrm{a}$ & & $11.5 \mathrm{c}$ & & $17.1 \mathrm{c}$ & & $0.67 \mathrm{~b}$ & & $7.8 \mathrm{a}$ & \\
\hline- & + & $230 \mathrm{a}$ & $4 \%$ & $10.5 \mathrm{~d}$ & $-9 \%$ & $14.9 \mathrm{~d}$ & $-13 \%$ & $0.71 \mathrm{a}$ & $6 \%$ & $8.1 \mathrm{a}$ & $4 \%$ \\
\hline+ & - & $116 \mathrm{c}$ & & $13.7 \mathrm{a}$ & & $21.6 \mathrm{a}$ & & $0.63 \mathrm{c}$ & & $6.8 \mathrm{c}$ & \\
\hline+ & + & $185 \mathrm{~b}$ & $59 \%$ & $12.8 \mathrm{~b}$ & $-7 \%$ & $19.3 \mathrm{~b}$ & $-11 \%$ & $0.66 \mathrm{~b}$ & $5 \%$ & $7.2 \mathrm{~b}$ & $6 \%$ \\
\hline \multicolumn{12}{|c|}{ Abaxial face } \\
\hline- & - & $657 \mathrm{a}$ & & $10.1 \mathrm{c}$ & & $14.4 \mathrm{c}$ & & $0.71 \mathrm{a}$ & & $18.3 \mathrm{a}$ & \\
\hline- & + & $678 \mathrm{a}$ & $3 \%$ & $9.7 \mathrm{c}$ & $-4 \%$ & $13.7 \mathrm{c}$ & $-5 \%$ & $0.72 \mathrm{a}$ & $1 \%$ & $18.7 \mathrm{a}$ & $2 \%$ \\
\hline+ & - & $600 c$ & & $13.2 \mathrm{a}$ & & $20.5 \mathrm{a}$ & & $0.64 \mathrm{c}$ & & $15.3 \mathrm{c}$ & \\
\hline+ & + & $628 b$ & $5 \%$ & $12.6 \mathrm{~b}$ & $-5 \%$ & $19.1 \mathrm{~b}$ & $-7 \%$ & $0.67 \mathrm{~b}$ & $5 \%$ & $16.8 \mathrm{~b}$ & $10 \%$ \\
\hline \multicolumn{12}{|c|}{ Leaf anatomy } \\
\hline $\mathrm{Ni}$ & EBR & \multicolumn{2}{|c|}{ ETAd $(\mu \mathrm{m})$} & \multicolumn{2}{|c|}{$\operatorname{ETAb}(\mu \mathrm{m})$} & \multicolumn{2}{|c|}{$\mathrm{PPT}(\mu \mathrm{m})$} & \multicolumn{2}{|c|}{$\mathrm{SPT}(\mu \mathrm{m})$} & \multicolumn{2}{|c|}{$\begin{array}{l}\text { Ratio } \\
\text { PPT/SPT }\end{array}$} \\
\hline- & - & $19.2 \mathrm{a}$ & & $15.9 \mathrm{~b}$ & & $65 \mathrm{a}$ & & $99 \mathrm{a}$ & & $0.66 \mathrm{~b}$ & \\
\hline- & + & $20.8 \mathrm{a}$ & $8 \%$ & $17.2 \mathrm{a}$ & $8 \%$ & $66 a$ & $2 \%$ & $103 a$ & $4 \%$ & $0.64 \mathrm{~b}$ & $-3 \%$ \\
\hline+ & - & $16.3 \mathrm{~b}$ & & $13.6 \mathrm{c}$ & & $56 \mathrm{~b}$ & & $73 \pm 1 \mathrm{c}$ & & $0.77 \mathrm{a}$ & \\
\hline+ & + & $17.1 \mathrm{~b}$ & $5 \%$ & $14.7 \mathrm{c}$ & $8 \%$ & $61 \mathrm{a}$ & $9 \%$ & $82 b$ & $12 \%$ & $0.75 a$ & $-3 \%$ \\
\hline
\end{tabular}

$\mathrm{SD}=$ Stomatal density $; \mathrm{PDS}=$ Polar diameter of the stomata $; \mathrm{EDS}=$ Equatorial diameter of the stomata $\mathrm{SF}=$ Stomatal functionality; $\mathrm{SI}=$ Stomatal index $;$ ETAd $=$ Epidermis thickness from adaxial leaf side; ETAb = Epidermis thickness from abaxial leaf side; PPT = Palisade parenchyma thickness; $\mathrm{SPT}=$ Spongy parenchyma thickness. Comparison with similar treatment without EBR. Columns with different letters indicate significant differences from the Scott-Knott test $(P<0.05)$. Values described corresponding to means from five repetitions and standard deviations and $\mathrm{F}_{\mathrm{v}} / \mathrm{F}_{\mathrm{m}}$. Significant decrease in $\mathrm{F}_{0}$ of plants exposed to EBR and $\mathrm{Ni}$ is an interesting result, because $\mathrm{F}_{0}$ represents the number of closed reaction centres or unable to receive light, resulting in an improvement in photon capture efficiency with intrinsic repercussions on $\mathrm{F}_{\mathrm{v}}$ and $\mathrm{F}_{\mathrm{v}} / \mathrm{F}_{\mathrm{m}}$ (Maxwell and Johnson 2000; Baker 2008). This steroid also reduced the photoinhibition intensity, avoiding damages on reaction centres and increased and transfer capacity of the excitation energy from the antenna to the PSII (Hayat et al. 2010; Qin et al. 2016). On the other hand, $\mathrm{Ni}^{2+}$ is potentially toxic to the photosynthetic apparatus, causing disorganization of the chloroplast ultrastructure, as well as deformation and decreases in the number of grana and thylakoids (Seregin and Kozhevnikova 2006). Drążkiewicz and Baszyński (2010) revealed reductions of $63 \%$ in $\mathrm{F}_{\mathrm{v}}$ of Zea mays seedlings exposed to $200 \mu \mathrm{M} \mathrm{Ni}^{2+}$ for 13 days. Yusuf et al. (2014), evaluating the EBR effects on the antioxidant system and nitrogen metabolism in two contrasting cultivars of Vigna radiata under different levels of $\mathrm{Ni}^{2+}$, reported increases in $\mathrm{F}_{\mathrm{v}} / \mathrm{F}_{\mathrm{m}}$ of the $\mathrm{T}-44$ cultivar submitted to $\mathrm{Ni}^{2+}$ and EBR.

EBR spray promoted increases in $\Phi_{\mathrm{PSII}}, \mathrm{q}_{\mathrm{P}}$ and ETR values in plants subjected to $\mathrm{Ni}^{2+}$ toxicity, and these results were related to the beneficial effects promoted in $\mathrm{F}_{0}$ and $\mathrm{F}_{\mathrm{v}}$ mentioned previously in this study. EBR resulted in an increase in the photon capture efficiency, promoting greater energy absorption and electron transport through the photosystems
(Dallagnol et al. 2015; Kumari et al. 2017), inducing increases in the efficiency of plastoquinones (Chen et al. 2005) and the cytochrome $b_{6} / f$ complex $\left(\mathrm{C} y t-b_{6} / f\right)$ that are responsible for the transfer of electrons from PSII to PSI (Buonasera et al. 2011). Pietrini et al. (2015) detected progressive reductions in $\Phi_{\text {PSII }}$ and $\mathrm{q}_{\mathrm{P}}$ values while investigating Amaranthus paniculatus plants exposed to progressive concentrations of $\mathrm{NiCl}_{2}$. Santos et al. (2018) evaluated the chlorophyll fluorescence, gas exchange and pigments in Vigna unguiculata plants pretreated with EBR and exposed to heavy metal $(\mathrm{Cd})$ and found increases of $55 \%$ in the ETR of plants exposed to EBR and metal toxicity.

Eucalyptus urophylla plants exposed to $\mathrm{Ni}^{2+}+\mathrm{EBR}$ showed reductions in NPQ, EXC and ETR $/ P_{\mathrm{N}}$, suggesting a better use of the electrons for photochemical activity, because the EBR effects reduced the thermal dissipation caused by excessive excitation in the antenna complex of PSII, consequently decreasing the photoinhibition (Ghassemi-Golezani and Lotfi 2015). Decreases in ETR $/ P_{\mathrm{N}}$ indicate that EBR minimized the alternative drains of electrons, thus minimizing Mehler's reactions (Silva et al. 2012; Jesus et al. 2017). Li et al. (2015) studied the effects of cadmium stress on chlorophyll fluorescence and photosynthesis and observed increases of $73 \%$ for NPQ in Elsholtzia argyi plants exposed to $100 \mu \mathrm{mol} \mathrm{L}{ }^{-1} \mathrm{Cd}$, corroborating the results of this study. 
Fig. 3 Leaf cross sections in young Eucalyptus urophylla plants sprayed with EBR and exposed to Ni toxicity. $-\mathrm{Ni}^{2+} /-$ $\operatorname{EBR}(\mathbf{A}),-\mathrm{Ni}^{2+} /+\operatorname{EBR}(\mathbf{B}),+$ $\mathrm{Ni}^{2+} /-\mathrm{EBR}(\mathbf{C})$ and $+\mathrm{Ni}^{2+} /+$ EBR (D). Legends: EAd $=$ adaxial epidermis; $\mathrm{EAb}=$ Adaxial epidermis; $\mathrm{PP}=$ Palisade parenchyma; $\mathrm{SP}=$ Spongy parenchyma. Bars: $200 \mu \mathrm{m}$

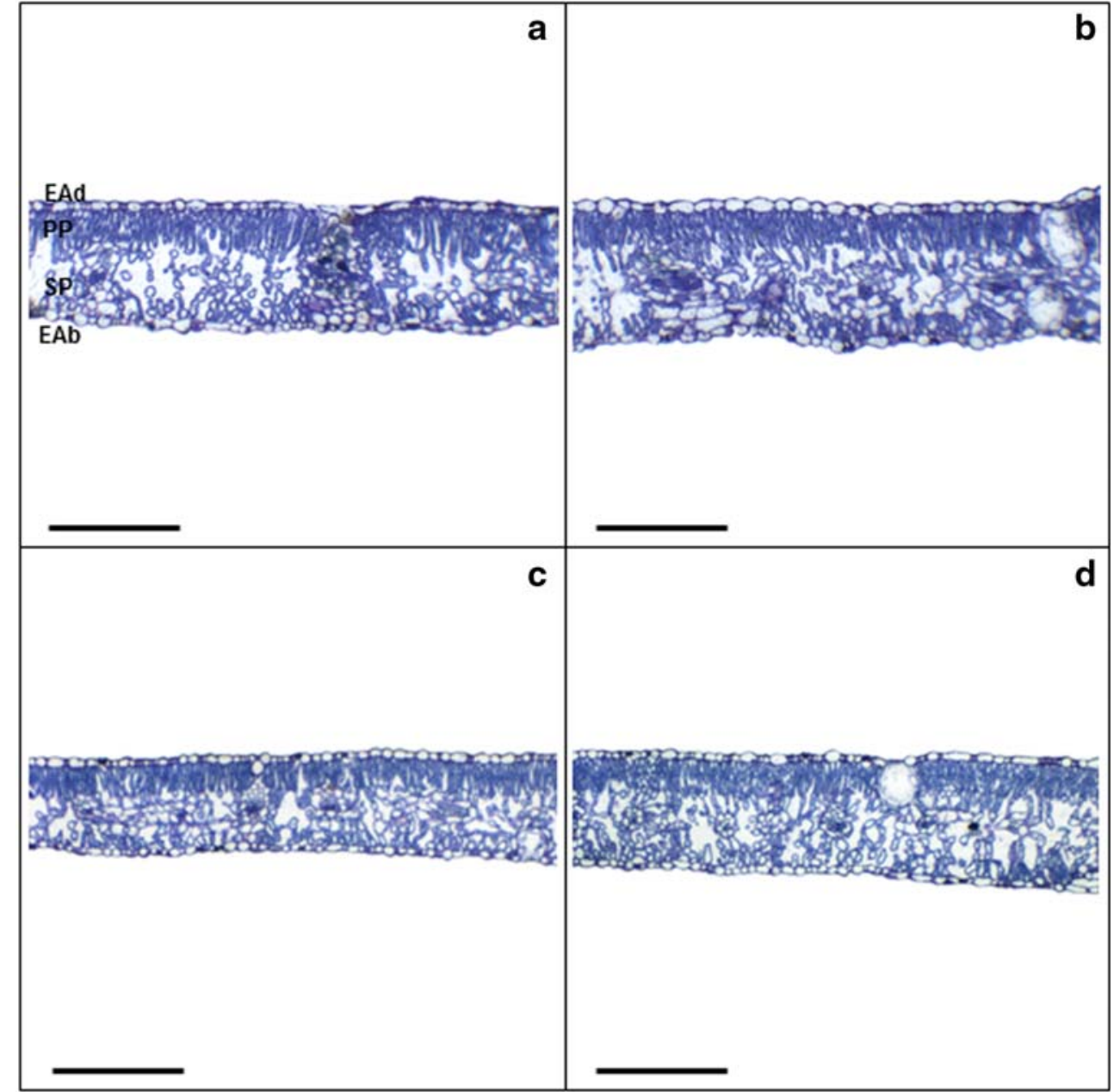

EBR application promoted increases in $P_{\mathrm{N}}, E, g_{\mathrm{s}}$, WUE and $P_{\mathrm{N}} / C_{\mathrm{i}}$ values, mitigating the effects induced by $\mathrm{Ni}^{2+}$ toxicity. The effect of EBR on $P_{\mathrm{N}}$ may be associated with better stomatal performance, as confirmed by the increase in $g_{\mathrm{s}}, \mathrm{SD}$, $\mathrm{SF}$ and SI values. The higher values of WUE after treatment with EBR may be related to the increase in $P_{\mathrm{N}}$ values, indicating a balance between $P_{\mathrm{N}}$ and water absorption in the studied plants (Kočová et al. 2010; Bhalerao et al. 2015). Ali et al. (2008) evaluated Brassica juncea plants grown in the presence of $\mathrm{NaCl}$ and/or $\mathrm{NiCl}_{2}$ and sprayed with $1 \mu \mathrm{M}$ of EBR detected increases in $P_{\mathrm{N}}, g_{\mathrm{s}}$ and WUE after EBR treatment. Khaliq et al. (2015) cultivated Gossypium hirsutum seedlings under hydroponic conditions for 12 weeks with three Ni levels $(0,50$ and $100 \mu \mathrm{M})$ combined with the presence or absence of $1 \mathrm{mM} \mathrm{Si}$ and observed that Ni significantly decreased several photosynthetic parameters, such as $E$.

The increase found in $P_{\mathrm{N}} / C_{\mathrm{i}}$ and the simultaneous reduction of $C_{\mathrm{i}}$ can be explained by the EBR interference with the $\mathrm{RuBisCO}$ enzyme activity, which is mainly responsible for catalysing the photosynthetic reaction of fixation and reduction of $\mathrm{CO}_{2}$ during photosynthesis (Andersson and Backlund 2008; Parry et al. 2013; Erb and Zarzycki 2018). Santos et al.
(2018) verified the effects of three EBR concentrations (0, 50 and $100 \mathrm{nM}$ ) on gas exchange and stress oxidation of Vigna unguiculata plants subjected to $\mathrm{Cd}$ toxicity and found decreases of $8 \%$ in plants sprayed with $100 \mathrm{nM}$ in comparison with equal treatment without EBR. Maia et al. (2018) evaluated the effects of EBR (100 nM EBR) in two Solanum lycopersicum genotypes and described increases of $37 \%$ and $48 \%$ in $P_{\mathrm{N}} / C_{\mathrm{i}}$ of the BR-efficient and BR-deficient genotypes, respectively.

Positive effects on SD, SF and SI were detected in plants treated with EBR, emphasizing the beneficial action of this steroid on stomatal performance, which can be corroborated by the increases of $g_{\mathrm{s}}$ and $E$ previously reported in this study. The increases in SD and SI were accompanied by a decrease in the size of the guard cells (Hetherington and Woodward 2003; Galmés et al. 2007) and increased $\mathrm{CO}_{2}$ uptake, which is a limiting factor for photosynthesis (Zhou and Han 2005). In relation to SF, the increases of these values suggest that EBR favoured a greater WUE, which is supported by the increase in WUE and decreases in PDS and EDS. The decreases found in PDS and EDS suggest an elliptic form of stomata, which, to maintain functionality, is continuously 


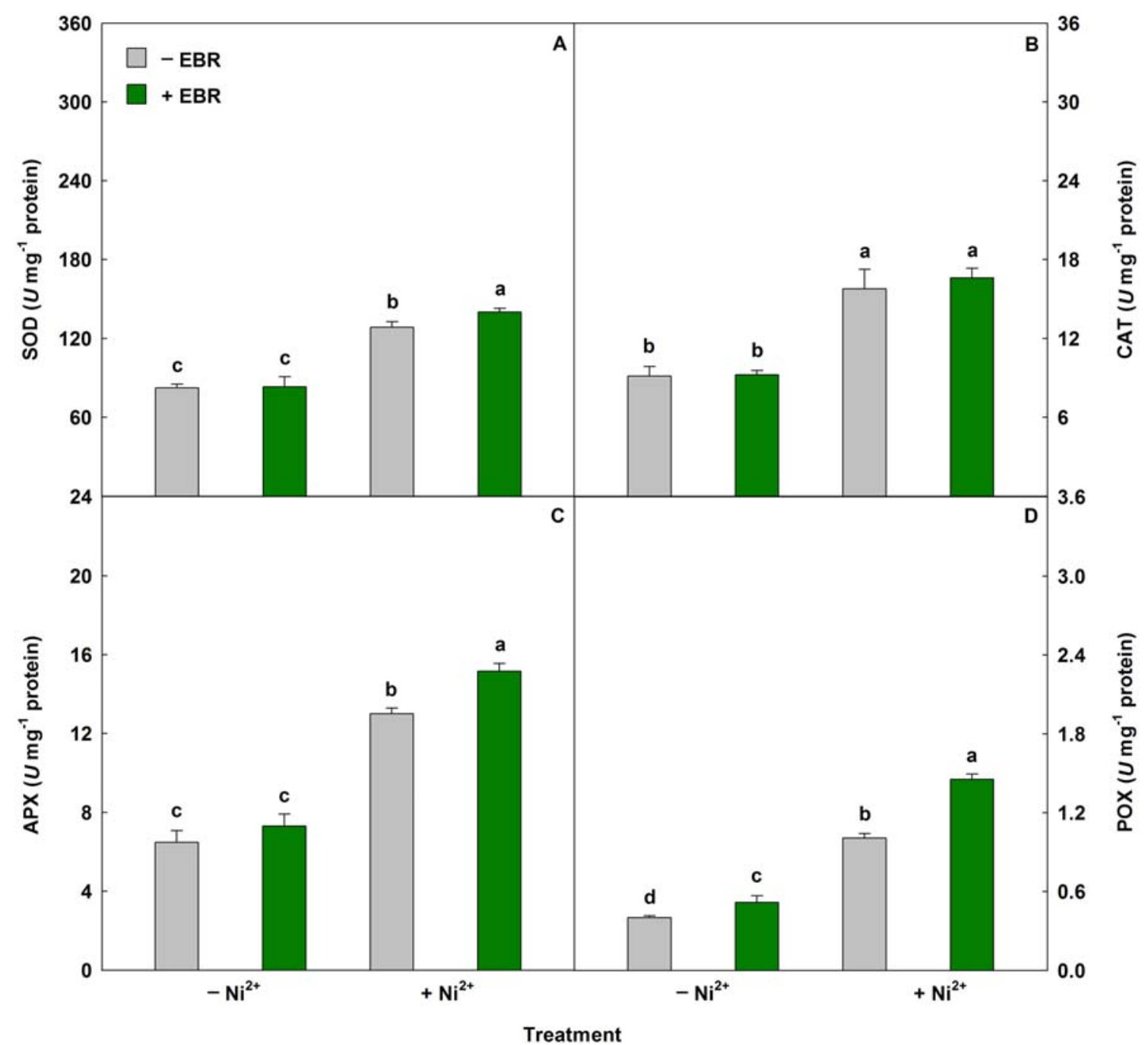

Fig. 4 Activities of superoxide dismutase (SOD), catalase (CAT), ascorbate peroxidase (APX) and peroxidase (POX) in young Eucalyptus urophylla plants sprayed with EBR and exposed to $\mathrm{Ni}$

adjusting to the environmental and intracellular conditions (Lawson and Blatt 2014). Adamski et al. (2012) evaluated $\mathrm{Fe}$ excess at concentrations of $0.45,0.9,4.5$, and $9.0 \mathrm{mmol} \mathrm{L}^{-1}$ in Ipomoea batatas and detected increases in PDS and EDS of the stomata on the abaxial face of the leaves at the highest concentrations of $\mathrm{Fe}\left(4.5\right.$ and $\left.9.0 \mathrm{mmol} \mathrm{L}^{-1}\right)$. Sagardoy et al. (2010) investigated the effects of $\mathrm{Zn}$ toxicity on photosynthesis and respiration in Beta vulgaris plants hydroponically cultivated with $1.2,100$ or $300 \mu \mathrm{M} Z \mathrm{Zn}$ and detected a decrease in the density and size of the stomata, corroborating the results found in this study.

EBR had positive effects on leaf anatomy (ETAd, ETAb, PPT and SPT). The increases in ETAd and ETAb are related to the benefits promoted by EBR on leaf tissues, more specifically the epidermis and mesophyll, suggesting an efficient strategy to minimize water loss through $E$, as demonstrated by the increases verified in WUE as previously described in our study. In relation to PPT and SPT, the increases obtained toxicity. Columns with different letters indicate significant differences from the Scott-Knott test $(P<0.05)$. Columns corresponding to means from five repetitions and standard deviations

can be corroborated by the increases in $P_{\mathrm{N}}$ and $P_{\mathrm{N}} / C_{\mathrm{i}}$ and SI because the PPT is rich in chloroplasts and is fundamental for the absorption of light during photosynthesis and fixation of $\mathrm{CO}_{2}$. Additionally, SPT is known to be involved in gas exchange (Sorin et al. 2015). Maruthi Sridhar et al. (2005) observed a reduction in the cell sizes of the palisade parenchyma and epidermis in Brassica juncea leaves exposed to $\mathrm{Zn}$ and $\mathrm{Cd}$ for 15 and 16 days, respectively, which is in agreement with the results obtained in this study.

Positive effects on SOD, CAT, APX and POX were detected in plants treated with $\mathrm{Ni}^{2+}+\mathrm{EBR}$, corroborating the beneficial actions of EBR on the antioxidant system. The results obtained demonstrated that EBR has the ability to regulate the antioxidant system to reduce ROS (Rajewska et al. 2016), which can be supported by the decrease of $\mathrm{H}_{2} \mathrm{O}_{2}$ and increase of ETR after treatment with EBR. Kanwar et al. (2013) studied the effects of 24-epibrasionlide in Brassica juncea plants at 30 days of age exposed to different Ni levels and found an 


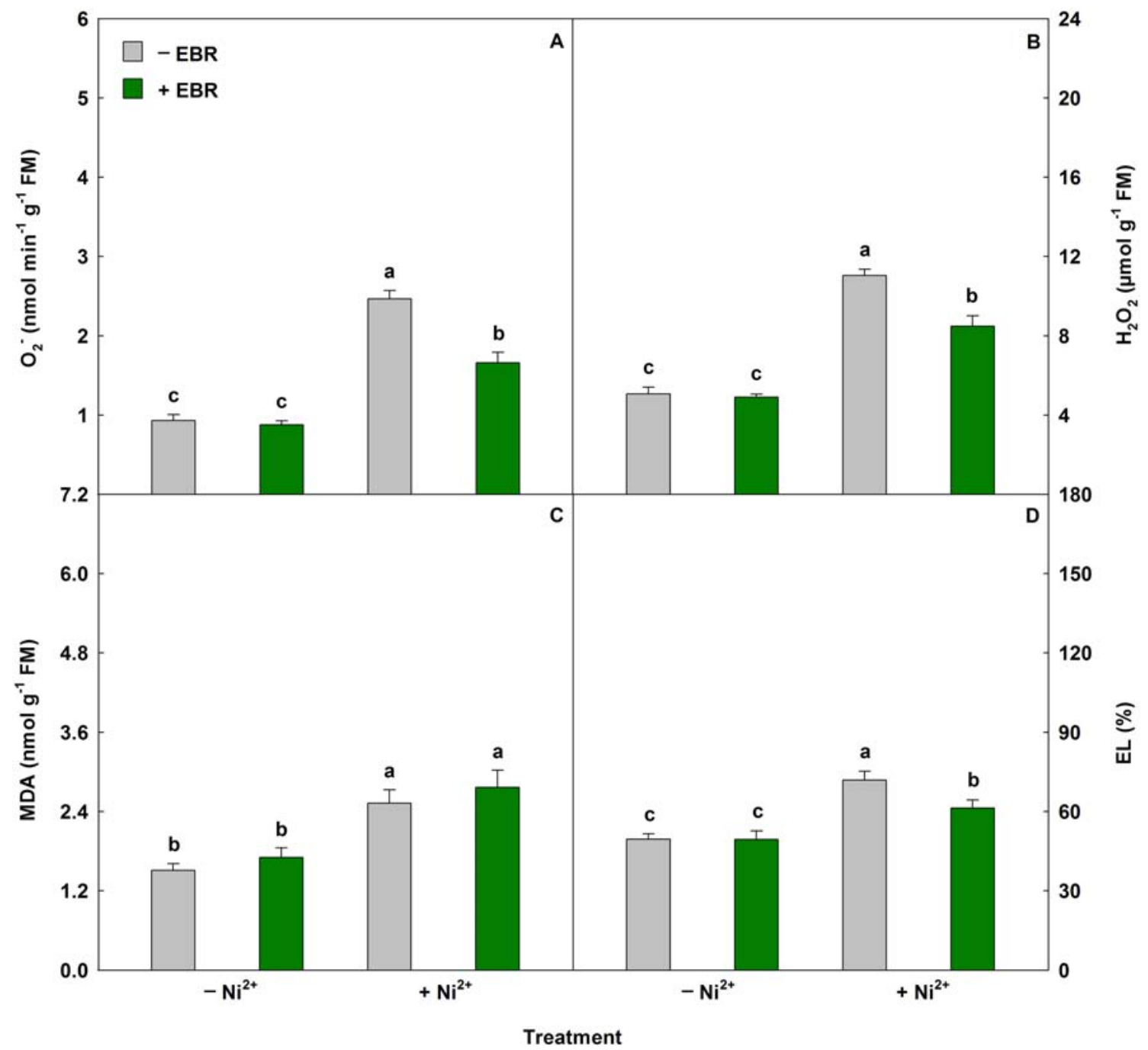

Fig. 5 Superoxide $\left(\mathrm{O}_{2}{ }^{-}\right)$, hydrogen peroxide $\left(\mathrm{H}_{2} \mathrm{O}_{2}\right)$, malondialdehyde (MDA) and electrolyte leakage (EL) in young Eucalyptus urophylla plants sprayed with EBR and exposed to Ni toxicity. Columns with different letters indicate significant differences from the Scott-Knott test $(P<0.05)$. Columns corresponding to means from five repetitions and standard deviations

et al. 2003; Gajewska and Skłodowska 2008). In regard to the $\mathrm{O}_{2}{ }^{-}$and $\mathrm{H}_{2} \mathrm{O}_{2}$ reductions, the EBR action stimulated the $\mathrm{SOD}$ activity, which led to an increase of $\mathrm{H}_{2} \mathrm{O}_{2}$ and consequent induction of CAT and APX activities, which act on $\mathrm{H}_{2} \mathrm{O}_{2}$, reducing the amount of oxidant compounds (Ashraf 2009; Yusuf et al. 2011a). Similar to this study, Soares et al. (2016) evaluating the effects of the exogenous application of EBR on physiological and biochemical responses of Solanum nigrum exposed to Ni toxicity over 28 days observed a decrease of $\mathrm{H}_{2} \mathrm{O}_{2}$ between plants treated with 24-EBL and $100 \mu \mathrm{M} \mathrm{NiSO}_{4}$ of $55 \%$ and $10 \%$ in shoot and root, respectively.

EBR spray mitigated the toxic effects of $\mathrm{Ni}^{2+}$, positively impacted the growth, and induced significant increases in LDM, RDM, SDM and TDM. These increases are intrinsically related to the benefits observed in this study on gas exchange, pigments, root anatomy and nutritional content, as well as reductions in oxidant compounds. $\mathrm{Ni}^{2+}$ toxicity dants, causing damage that eventually leads to cell death (Rio 


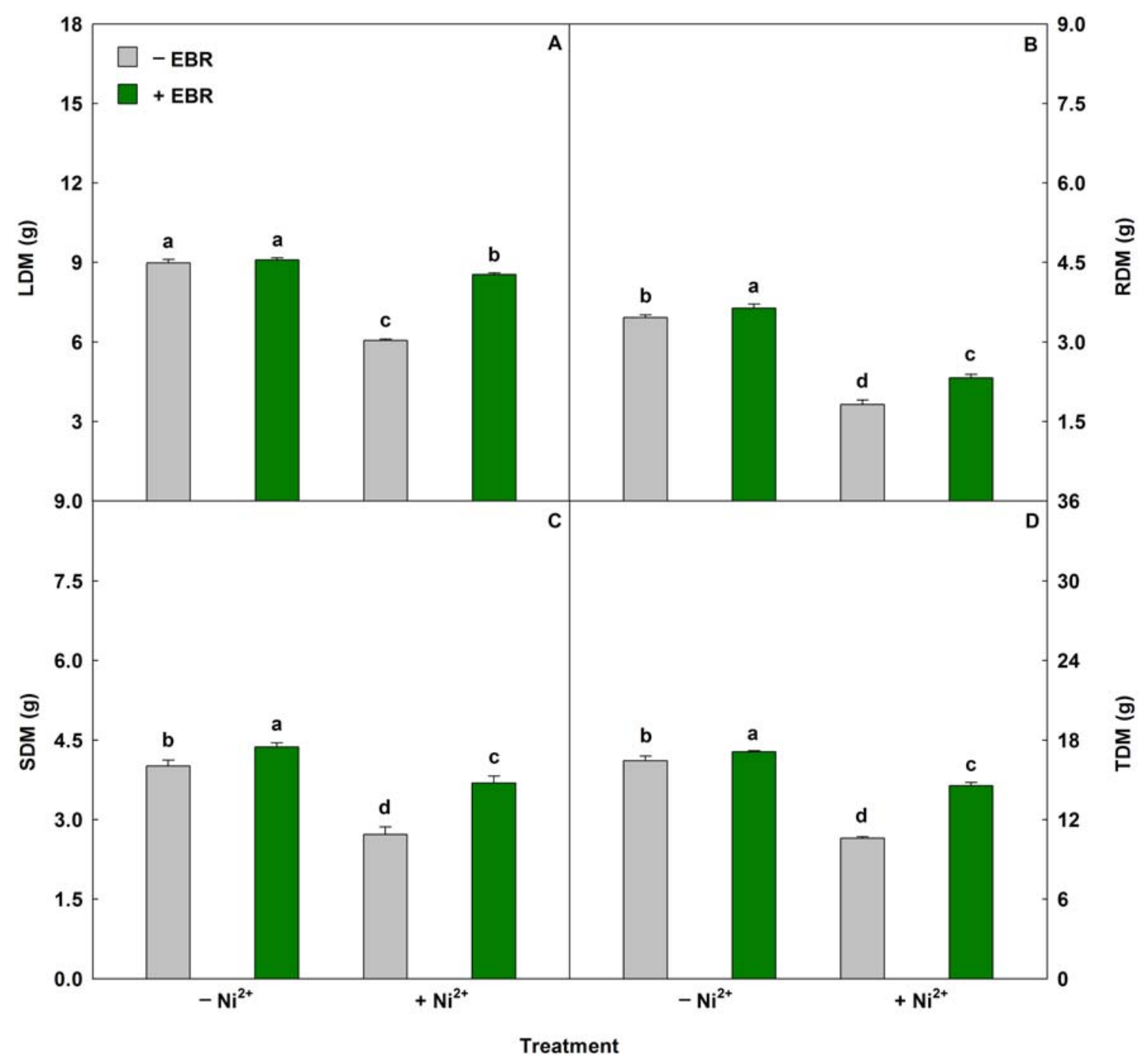

Fig. 6 Leaf dry matter (LDM), root dry matter (RDM), stem dry matter (SDM) and total dry matter (TDM) in young Eucalyptus urophylla plants sprayed with EBR and exposed to Ni toxicity. Columns with different

reduces plant growth due to disturbances in the photosynthetic apparatus, mainly disorganizing the chloroplast ultrastructure (Seregin and Kozhevnikova 2006; Feng et al. 2010), and through disorders in nutritional balance and decreases in Fe, $\mathrm{Ca}$ and $\mathrm{K}$ content, elements required in plant metabolism (Sharma and Dhiman 2013; Ali et al. 2015). Iori et al. (2013) evaluated the phytoremediation capacity of Amaranthus paniculatus subjected to progressive concentrations of $\mathrm{Ni}^{2+}$ and observed significant reductions in LDM, RDM and SDM when treated with $150 \mu \mathrm{m}$ of $\mathrm{Ni}^{2+}$. Alam et al. (2007) detected partial increases in RDM and SDM in Brassica juncea plants when treated with 50 and $100 \mu \mathrm{M} \mathrm{Ni}^{2+}$ + BRs, both corroborating the results obtained in this study.

In relation to Ni toxicity, this study proved that young Eucalyptus urophylla plants are more tolerant that other species previously evaluated by our research group (data not available), being necessary to use a higher Ni concentration letters indicate significant differences from the Scott-Knott test $(P<0.05)$. Columns corresponding to means from five repetitions and standard deviations

to simulate the toxicity, as well as symptoms were verified only ten days after Ni treatment. Future research using several Eucalyptus species can be interest to determinate possible tolerance levels and phytoremediation potential to each specie.

\section{Conclusion}

Our research revealed that EBR alleviated Ni toxicity in young Eucalyptus urophylla plants by modulating ionic homeostasis. This steroid clearly modulated the Ni contents and ionic ratios of $\mathrm{Mn}^{2+} \mathrm{Ni}^{2+}$ in tissues evaluated, being this result crucial to mitigate the Ni effects, because this heavy metal inhibits the absorption of other elements that are essentials to metabolism, including Mn, competing by similar transporters. Plants stressed had positive effects after EBR spray in relation to $\Phi_{\mathrm{PSII}}$ and $\mathrm{F}_{\mathrm{v}} / \mathrm{F}_{\mathrm{m}}$, being intrinsically linked to increases in 
Mn content, because this element is a component of enzymes related to the break down water molecules in PSII during water photolysis. Considering the increases detected for antioxidant enzymes, photosynthetic pigments and biomass, these results confirm that EBR reduces oxidative stress, alleviating the deleterious effects induced by Ni toxicity.

Contribution of co-authors AKSL was the advisor of this research. ATR, VPO and UOBJ conducted the experiment in the greenhouse and performed physiological, biochemical and morphological determinations, while BRSS measured anatomical parameters and BLB performed nutritional determinations.

Data availability statement The datasets generated during this research are available in the Zenodo repository (Ribeiro et al. 2019) at https://doi.org/10.5281/zenodo.3552032

Fundings This research had financial supports from Fundação Amazônia de Amparo a Estudos e Pesquisas (FAPESPA/ Brazil), Conselho Nacional de Desenvolvimento Científico e Tecnológico (CNPq/Brazil) and Universidade Federal Rural da Amazônia (UFRA/Brazil) to AKSL. On the other hand, ATR and VPO were supported with scholarships from Programa de Educação Tutorial (PET/Brazil).

\section{Compliance with ethical standards}

Conflict of interest The authors declare that they have no competing interests.

\section{References}

Adamski JM, Danieloski R, Deuner S, Braga EJB, Castro LAS, Peters JA (2012) Responses to excess iron in sweet potato: impacts on growth, enzyme activities, mineral concentrations, and anatomy. Acta Physiol Plant 34:1827-1836. https://doi.org/10.1007/s11738-0120981-3

Ahammed GJ, Choudhary SP, Chen S, Xia X, Shi K, Zhou Y, Yu J (2013a) Role of brassinosteroids in alleviation of phenanthrenecadmium co-contamination-induced photosynthetic inhibition and oxidative stress in tomato. J Exp Bot 64:199-213. https://doi.org/ $10.1093 / \mathrm{jxb} / \mathrm{ers} 323$

Ahammed GJ, Choudhary SP, Chen S, Xia X, Shi K, Zhou Y, Yu J (2013b) Role of brassinosteroids in alleviation of phenanthrenecadmium co-contamination-induced photosynthetic inhibition and oxidative stress in tomato. J Exp Bot 64:199-213. https://doi.org/ $10.1093 /$ jxb/ers 323

Ahmad MSA, Hussain M, Saddiq R, Alvi AK (2007) Mungbean: a nickel indicator, accumulator or excluder? Bull Environ Contam Toxicol 78:319-324. https://doi.org/10.1007/s00128-007-9182-y

Alam MM, Hayat S, Ali B, Ahmad A (2007) Effect of 28homobrassinolide treatment on nickel toxicity in Brassica juncea. Photosynthetica 45:139-142. https://doi.org/10.1007/s11099-0070022-4

Ali B, Hayat S, Fariduddin Q, Ahmad A (2008) 24-Epibrassinolide protects against the stress generated by salinity and nickel in Brassica juncea. Chemosphere 72:1387-1392. https://doi.org/10.1016/j. chemosphere.2008.04.012

Ali E, Maodzeka A, Hussain N, Shamsi IH, Jiang L (2015) The alleviation of cadmium toxicity in oilseed rape (Brassica napus) by the application of salicylic acid. Plant Growth Regul 75:641-655. https://doi.org/10.1007/s10725-014-9966-0

Amari T, Ghnaya T, Debez A, Taamali M, Ben Youssef N, Lucchini G, Sacchi GA, Abdelly C (2014) Comparative Ni tolerance and accumulation potentials between Mesembryanthemum crystallinum (halophyte) and Brassica juncea: metal accumulation, nutrient status and photosynthetic activity. J Plant Physiol 171:1634-1644. https:// doi.org/10.1016/j.jplph.2014.06.020

Andersson I, Backlund A (2008) Structure and function of Rubisco. Plant Physiol Biochem 46:275-291. https://doi.org/10.1016/j.plaphy. 2008.01.001

Aravind P, Prasad MNV (2004) Zinc protects chloroplasts and associated photochemical functions in cadmium exposed Ceratophyllum demersum L., a freshwater macrophyte. Plant Sci 166:1321-1327. https://doi.org/10.1016/j.plantsci.2004.01.011

Aroca R, Porcel R, Ruiz-Lozano JM (2012) Regulation of root water uptake under abiotic stress conditions. J Exp Bot 63:43-57. https:// doi.org/10.1093/jxb/err266

Ashraf M (2009) Biotechnological approach of improving plant salt tolerance using antioxidants as markers. Biotechnol Adv 27:84-93. https://doi.org/10.1016/j.biotechadv.2008.09.003

Ashraf MY, Sadiq R, Hussain M, Ashraf M, Ahmad MS (2011) Toxic effect of nickel (Ni) on growth and metabolism in germinating seeds of sunflower (Helianthus annuus L.). Biol Trace Elem Res 143: 1695-1703. https://doi.org/10.1007/s12011-011-8955-7

Atabayeva S, Nurmahanova A, Akhmetova A et al (2016) Anatomical peculiarities in wheat (Triticum aestivum L.) varieties under copper stress. Pakistan J Bot 48:1399-1405

Badawi GH, Yamauchi Y, Shimada E et al (2004) Enhanced tolerance to salt stress and water deficit by overexpressing superoxide dismutase in tobacco (Nicotiana tabacum) chloroplasts. Plant Sci 166:919928. https://doi.org/10.1016/j.plantsci.2003.12.007

Bajguz A, Hayat S (2009) Effects of brassinosteroids on the plant responses to environmental stresses. Plant Physiol Biochem 47:1-8. https://doi.org/10.1016/j.plaphy.2008.10.002

Bajguz A, Piotrowska-Niczyporuk A (2014) Interactive effect of brassinosteroids and cytokinins on growth, chlorophyll, monosaccharide and protein content in the green alga Chlorella vulgaris (Trebouxiophyceae). Plant Physiol Biochem 80:176-183. https:// doi.org/10.1016/j.plaphy.2014.04.009

Baker NR (2008) Chlorophyll fluorescence: a probe of photosynthesis in vivo. Annu Rev Plant Biol 59:89-113. https://doi.org/10.1146/ annurev.arplant.59.032607.092759

Bazihizina N, Redwan M, Taiti C et al (2015) Root based responses account for Psidium guajava survival at high nickel concentration. J Plant Physiol 174:137-146. https://doi.org/10.1016/j.jplph.2014. 10.011

Bhalerao SA, Sharma AS, Poojari AC (2015) Toxicity of nickel in plants. Int J Pure Appl Biosci 3:345-355. https://doi.org/10.1086/349961

Bityutskii N, Pavlovic J, Yakkonen K et al (2014) Contrasting effect of silicon on iron, zinc and manganese status and accumulation of metal-mobilizing compounds in micronutrient-deficient cucumber. Plant Physiol Biochem 74:205-211. https://doi.org/10.1016/j. plaphy.2013.11.015

Bradford MM (1976) A rapid and sensitive method for the quantitation of microgram quantities of protein utilizing the principle of protein-dye binding. Anal Biochem 72:248-254. https://doi.org/10.1016/00032697(76)90527-3

Buonasera K, Lambreva M, Rea G, Touloupakis E, Giardi MT (2011) Technological applications of chlorophyll a fluorescence for the assessment of environmental pollutants. Anal Bioanal Chem 401: 1139-1151. https://doi.org/10.1007/s00216-011-5166-1 
Cakmak I, Horst WJ (1991) Effect of aluminium on lipid peroxidation, superoxide dismutase, catalase, and peroxidase activities in root tips of soybean (Glycine max). Physiol Plant 83:463-468. https://doi. org/10.1111/j.1399-3054.1991.tb00121.x

Cakmak I, Marschner H (1992) Magnesium deficiency and high light intensity enhance activities of superoxide dismutase, ascorbate peroxidase, and glutathione reductase in bean leaves. Plant Physiol 98: 1222-1227. https://doi.org/10.1104/pp.98.4.1222

Chen LS, Qi YP, Smith BR, Liu XH (2005) Aluminum-induced decrease in $\mathrm{CO} 2$ assimilation in citrus seedlings is unaccompanied by decreased activities of key enzymes involved in $\mathrm{CO} 2$ assimilation. Tree Physiol 25:317-324. https://doi.org/10.1093/treephys/25.3.317

Chen C, Huang D, Liu J (2009) Functions and toxicity of nickel in plants: recent advances and future prospects. CLEAN - Soil, Air, Water 37: 304-313. https://doi.org/10.1002/clen.200800199

Choudhary SP, Yu J-Q, Yamaguchi-Shinozaki K, Shinozaki K, Tran LS (2012) Benefits of brassinosteroid crosstalk. Trends Plant Sci 17: 594-605. https://doi.org/10.1016/j.tplants.2012.05.012

Cristancho RJA, Hanafi MM, Omar SRS, Rafii MY (2014) Aluminum speciation of amended acid tropical soil and its effects on plant root growth. J Plant Nutr 37:811-827. https://doi.org/10.1080/ 01904167.2014 .881856

Dallagnol LJ, Martins SCV, DaMatta FM, Rodrigues FÁ (2015) Brown spot negatively affects gas exchange and chlorophyll a fluorescence in rice leaves. Trop Plant Pathol 40:275-278. https://doi.org/10. 1007/s40858-015-0026-8

Demidchik V (2015) Mechanisms of oxidative stress in plants: from classical chemistry to cell biology. Environ Exp Bot 109:212-228. https://doi.org/10.1016/j.envexpbot.2014.06.021

Deng THB, Tang YT, van der Ent A et al (2016) Nickel translocation via the phloem in the hyperaccumulator Noccaea caerulescens (Brassicaceae). Plant Soil 404:35-45. https://doi.org/10.1007/ s11104-016-2825-1

Djebali W, Zarrouk M, Brouquisse R, el Kahoui S, Limam F, Ghorbel MH, Chaïbi W (2005) Ultrastructure and lipid alterations induced by cadmium in tomato (Lycopersicon esculentum) chloroplast membranes. Plant Biol 7:358-368. https://doi.org/10.1055/s-2005837696

Drążkiewicz M, Baszyński T (2010) Interference of nickel with the photosynthetic apparatus of Zea mays. Ecotoxicol Environ Saf 73:982986. https://doi.org/10.1016/j.ecoenv.2010.02.001

Dubey D, Pandey A (2011) Effect of nickel (Ni) on chlorophyll, lipid peroxidation and antioxidant enzymes activities in black gram (Vigna mungo) leaves. Int J Sci Nat 2:395-401

Edel KH, Kudla J (2016) Integration of calcium and ABA signaling. Curr Opin Plant Biol 33:83-91. https://doi.org/10.1016/j.pbi.2016.06. 010

Elstner EF, Heupel A (1976) Inhibition of nitrite formation from hydroxylammoniumchloride: a simple assay for superoxide dismutase. Anal Biochem 70:616-620. https://doi.org/10.1016/00032697(76)90488-7

Erb TJ, Zarzycki J (2018) A short history of RubisCO: the rise and fall (?) of nature's predominant $\mathrm{CO} 2$ fixing enzyme. Curr Opin Biotechnol 49:100-107. https://doi.org/10.1016/j.copbio.2017.07.017

Fariduddin Q, Yusuf M, Ahmad I, Ahmad A (2014) Brassinosteroids and their role in response of plants to abiotic stresses. Biol Plant 58:9-17. https://doi.org/10.1007/s10535-013-0374-5

Feng J, Shi Q, Wang X et al (2010) Silicon supplementation ameliorated the inhibition of photosynthesis and nitrate metabolism by cadmium (Cd) toxicity in Cucumis sativus L. Sci Hortic (Amsterdam) 123: 521-530. https://doi.org/10.1016/j.scienta.2009.10.013

Gajewska E, Skłodowska M (2007) Relations between tocopherol, chlorophyll and lipid peroxides contents in shoots of Ni-treated wheat. J Plant Physiol 164:364-366. https://doi.org/10.1016/j.jplph.2006.05. 021
Gajewska E, Skłodowska M (2008) Differential biochemical responses of wheat shoots and roots to nickel stress: antioxidative reactions and proline accumulation. Plant Growth Regul 54:179-188. https://doi. org/10.1007/s10725-007-9240-9

Galmés J, Flexas J, Savé R, Medrano H (2007) Water relations and stomatal characteristics of mediterranean plants with different growth forms and leaf habits: responses to water stress and recovery. Plant Soil 290:139-155. https://doi.org/10.1007/s11104-006-9148-6

Gao J, Wang H, Yuan Q, Feng Y (2018) Structure and function of the photosystem supercomplexes. Front Plant Sci 9:1-7. https://doi.org/ 10.3389/fpls.2018.00357

Garcia JS, Dalmolin ÂC, Cortez PA, Barbeira PS, Mangabeira PAO, França MGC (2018) Short-term cadmium exposure induces gas exchanges, morphological and ultrastructural disturbances in mangrove Avicennia schaueriana young plants. Mar Pollut Bull 131: 122-129. https://doi.org/10.1016/j.marpolbul.2018.03.058

Ghassemi-Golezani K, Lotfi R (2015) The impact of salicylic acid and silicon on chlorophyll a fluorescence in mung bean under salt stress. Russ J Plant Physiol 62:611-616. https://doi.org/10.1134/ S1021443715040081

Giannopolitis CN, Ries SK (1977) Superoxide dismutases: I. occurrence in higher plants. Plant Physiol 59:309-314

Gomes MP, Marques TCLLSM, Carneiro MMLC, Soares ÂM (2012) Anatomical characteristics and nutrient uptake and distribution associated with the cd-phytoremediation capacity of Eucalyptus camaldulenses Dehnh. J Soil Sci Plant Nutr 12:481-495. https:// doi.org/10.4067/s0718-95162012005000010

Gong M, Li Y-J, Chen S-Z (1998) Abscisic acid-induced thermotolerance in maize seedlings is mediated by calcium and associated with antioxidant systems. J Plant Physiol 153:488-496. https://doi.org/10. 1016/S0176-1617(98)80179-X

Gowayed SMH, Almaghrabi OA (2013) Effect of copper and cadmium on germination and anatomical structure of leaf and root seedling in maize ( Zea mays L). Aust J Basic Appl Sci 7:548-555

Gudesblat GE, Russinova E (2011) Plants grow on brassinosteroids. Curr Opin Plant Biol 14:530-537. https://doi.org/10.1016/j.pbi.2011.05. 004

Hacham Y, Holland N, Butterfield C, Ubeda-Tomas S, Bennett MJ, Chory J, Savaldi-Goldstein S (2011) Brassinosteroid perception in the epidermis controls root meristem size. Development 138:839 848. https://doi.org/10.1242/dev.061804

Harasim P, Filipek T (2015) Nickel in the environment. J Elem 20:525534. https://doi.org/10.5601/jelem.2014.19.3.651

Havir EA, McHale NA (1987) Biochemical and developmental characterization of multiple forms of catalase in tobacco leaves. Plant Physiol 84:450-455. https://doi.org/10.1104/pp.84.2.450

Hayat S, Hasan SA, Yusuf M et al (2010) Effect of 28-homobrassinolide on photosynthesis, fluorescence and antioxidant system in the presence or absence of salinity and temperature in Vigna radiata. Environ Exp Bot 69:105-112. https://doi.org/10.1016/j.envexpbot. 2010.03.004

Hetherington AM, Woodward FI (2003) The role of stomata in sensing and driving environmental change. Nature 424:901-908. https://doi. org/10.1038/nature01843

Hoagland DR, Arnon DI (1950) The water-culture method for growing plants without soil, 2nd edn. California Agricultural Experiment Station

Hussain MB, Ali S, Azam A et al (2013) Morphological, physiological and biochemical responses of plants to nickel stress: a review. African J Agric Res 8:1596-1602. https://doi.org/10.5897/ AJAR12.407

IBÁ (2017) Anuário Estatístico da Indústria Brasileira de Árvore - 2017. 100. https://doi.org/10.1017/CBO9781107415324.004

Ibanes M, Fabregas N, Chory J, Cano-Delgado AI (2009) Brassinosteroid signaling and auxin transport are required to establish the periodic 
pattern of Arabidopsis shoot vascular bundles. Proc Natl Acad Sci 106:13630-13635. https://doi.org/10.1073/pnas.0906416106

Iori V, Pietrini F, Cheremisina A, Shevyakova NI, Radyukina N, Kuznetsov VV, Zacchini M (2013) Growth responses, metal accumulation and phytoremoval capability in amaranthus plants exposed to nickel under hydroponics. Water Air Soil Pollut 224:1-10. https:// doi.org/10.1007/s11270-013-1450-3

Javelle M, Vernoud V, Rogowsky PM, Ingram GC (2011) Epidermis: the formation and functions of a fundamental plant tissue. New Phytol 189:17-39. https://doi.org/10.1111/j.1469-8137.2010.03514.x

Jenbere D, Lemenih M, Kassa H (2012) Expansion of eucalypt farm forestry and its determinants in arsi negelle district, south Central Ethiopia. Small-scale For 11:389-405. https://doi.org/10.1007/ s11842-011-9191-x

Jesus LR, Batista BL, Lobato AKS (2017) Silicon reduces aluminum accumulation and mitigates toxic effects in cowpea plants. Acta Physiol Plant 39:138-114. https://doi.org/10.1007/s11738-0172435-4

Kanwar MK, Bhardwaj R, Chowdhary SP et al (2013) Isolation and characterization of 24-Epibrassinolide from Brassica juncea L. and its effects on growth, Ni ion uptake, antioxidant defense of Brassica plants and in vitro cytotoxicity. Acta Physiol Plant 35:1351-1362. https://doi.org/10.1007/s11738-012-1175-8

Khaliq A, Ali S, Hameed A et al (2015) Silicon alleviates nickel toxicity in cotton seedlings through enhancing growth, photosynthesis, and suppressing Ni uptake and oxidative stress. Arch Agron Soil Sci 62: 633-647. https://doi.org/10.1080/03650340.2015.1073263

Kočová M, Rothová O, Holá D, Kvasnica M, Kohout L (2010) The effects of brassinosteroids on photosynthetic parameters in leaves of two field-grown maize inbred lines and their F1 hybrid. Biol Plant 54:785-788. https://doi.org/10.1007/s10535-010-0143-7

Korzeniowska J, Stanislawska-Glubiak E (2019) Phytoremediation potential of Phalaris arundinacea, Salix viminalis and Zea mays for nickel-contaminated soils. Int J Environ Sci Technol 16:19992008. https://doi.org/10.1007/s13762-018-1823-7

Kumari J, Udawat P, Dubey AK, Haque MI, Rathore MS, Jha B (2017) Overexpression of SbSI-1, a nuclear protein from Salicornia brachiata confers drought and salt stress tolerance and maintains photosynthetic efficiency in transgenic tobacco. Front Plant Sci 8: 1215. https://doi.org/10.3389/fpls.2017.01215

Kuramshina ZM, Smirnova YV, Khairullin RM (2018) Cadmium and nickel toxicity for Sinapis alba plants inoculated with endophytic strains of Bacillus subtilis. Russ J Plant Physiol 65:269-277. https://doi.org/10.1134/S1021443718010077

Laanemets K, Brandt B, Li J, Merilo E, Wang YF, Keshwani MM, Taylor SS, Kollist H, Schroeder JI (2013) Calcium-dependent and independent stomatal signaling network and compensatory feedback control of stomatal opening via $\mathrm{Ca} 2+$ sensitivity priming. Plant Physiol 163:504-513. https://doi.org/10.1104/pp.113.220343

Lawson T, Blatt MR (2014) Stomatal size, speed, and responsiveness impact on photosynthesis and water use efficiency. Plant Physiol 164:1556-1570. https://doi.org/10.1104/pp.114.237107

Li S, Yang W, Yang T, Chen Y, Ni W (2015) Effects of cadmium stress on leaf chlorophyll fluorescence and photosynthesis of elsholtzia argyi — a cadmium accumulating plant. Int J Phytoremediation 17:85-92. https://doi.org/10.1080/15226514.2013.828020

Lichtenthaler HK, Buschmann C (2001) Chlorophylls and carotenoids: measurement and characterization by UV-VIS spectroscopy. In: Current protocols in food analytical chemistry. John Wiley \& Sons, Inc., Hoboken, NJ, USA, pp 431-438

Lima JV, Lobato AKS (2017) Brassinosteroids improve photosystem II efficiency, gas exchange, antioxidant enzymes and growth of cowpea plants exposed to water deficit. Physiol Mol Biol Plants 23:59 72. https://doi.org/10.1007/s12298-016-0410-y

Lima MDR, Barros Junior UO, Batista BL, Lobato AKS (2018) Brassinosteroids mitigate iron deficiency improving nutritional status and photochemical efficiency in Eucalyptus urophylla plants. Trees - Struct Funct 32:1681-1694. https://doi.org/10.1007/s00468018-1743-7

Lukatkin AS, Kashtanova NN, Duchovskis P (2013) Changes in maize seedlings growth and membrane permeability under the effect of epibrassinolide and heavy metals. Russ Agric Sci 39:307-310. https://doi.org/10.3103/S1068367413040125

Maia CF, Silva BRS, Lobato AKS (2018) Brassinosteroids positively modulate growth: physiological, biochemical and anatomical evidence using two tomato genotypes contrasting to dwarfism. J Plant Growth Regul 37:1-14. https://doi.org/10.1007/s00344-018-9802-2

Maksimović I, Kastori R, Krstić L, Luković J (2007) Steady presence of cadmium and nickel affects root anatomy, accumulation and distribution of essential ions in maize seedlings. Biol Plant 51:589-592. https://doi.org/10.1007/s10535-007-0129-2

Maruthi Sridhar BB, Diehl SV, Han FX et al (2005) Anatomical changes due to uptake and accumulation of $\mathrm{Zn}$ and $\mathrm{cd}$ in Indian mustard (Brassica juncea). Environ Exp Bot 54:131-141. https://doi.org/10. 1016/j.envexpbot.2004.06.011

Matraszek R, Hawrylak-Nowak B, Chwil S, Chwil M (2016) Macronutrient composition of nickel-treated wheat under different sulfur concentrations in the nutrient solution. Environ Sci Pollut Res 23:5902-5914. https://doi.org/10.1007/s11356-015-5823-6

Maxwell K, Johnson GN (2000) Chlorophyll fluorescence-a practical guide. J Exp Bot 51:659-668. https://doi.org/10.1093/jexbot/51. 345.659

Mellor N, Adibi M, El-Showk S et al (2017) Theoretical approaches to understanding root vascular patterning: a consensus between recent models. J Exp Bot 68:5-16. https://doi.org/10.1093/jxb/erw410

Mizuno T, Usui K, Horie K, Nosaka S, Mizuno N, Obata H (2005) Cloning of three ZIP/Nramp transporter genes from a $\mathrm{Ni}$ hyperaccumulator plant Thlaspi japonicum and their $\mathrm{Ni2}+-$ transport abilities. Plant Physiol Biochem 43:793-801. https://doi.org/10. 1016/j.plaphy.2005.07.006

Mora F, Arriagada O, Ballesta P, Ruiz E (2017) Genetic diversity and population structure of a drought-tolerant species of Eucalyptus, using microsatellite markers. J Plant Biochem Biotechnol 26:274 281. https://doi.org/10.1007/s13562-016-0389-z

Nagajyoti PC, Lee KD, Sreekanth TVM (2010) Heavy metals, occurrence and toxicity for plants: a review. Environ Chem Lett 8:199 216. https://doi.org/10.1007/s10311-010-0297-8

Nakano Y, Asada K (1981) Hydrogen peroxide is scavenged by ascorbate-specific peroxidase in spinach chloroplasts. Plant Cell Physiol 22:867-880

Neiva D, Fernandes L, Araújo S et al (2015) Chemical composition and Kraft pulping potential of 12 eucalypt species. Ind Crop Prod 66:89 95. https://doi.org/10.1016/j.indcrop.2014.12.016

Nie J, Pan Y, Shi J, Guo Y, Yan Z, Duan X, Xu M (2015) A comparative study on the uptake and toxicity of nickel added in the form of different salts to maize seedlings. Int J Environ Res Public Health 12:15075-15087. https://doi.org/10.3390/ijerph121214972

Nishida S, Tsuzuki C, Kato A et al (2011) AtIRT1, the primary iron uptake transporter in the root, mediates excess nickel accumulation in Arabidopsis thaliana. Plant Cell Physiol 52:1433-1442. https:// doi.org/10.1093/pcp/pcr089

O'Brien TP, Feder N, McCully ME (1964) Polychromatic staining of plant cell walls by toluidine blue O. Protoplasma 59:368-373

Ortega L, Fry SC, Taleisnik E (2006) Why are Chloris gayana leaves shorter in salt-affected plants? Analyses in the elongation zone. J Exp Bot 57:3945-3952. https://doi.org/10.1093/jxb/erl168

Pandey N, Sharma CP (2002) Effect of heavy metals Co2+, Ni2+ and $\mathrm{Cd} 2+$ on growth and metabolism of cabbage. Plant Sci 163:753758. https://doi.org/10.1016/S0168-9452(02)00210-8

Parry MAJ, Andralojc PJ, Scales JC et al (2013) Rubisco activity and regulation as targets for crop improvement. J Exp Bot 64:717-730. https://doi.org/10.1093/jxb/err313 
Pérez Chaca MV, Vigliocco A, Reinoso H, Molina A, Abdala G, Zirulnik F, Pedranzani H (2014) Effects of cadmium stress on growth, anatomy and hormone contents in Glycine max (L.) Merr. Acta Physiol Plant 36:2815-2826. https://doi.org/10.1007/s11738-014-1656-z

Pietrini F, Iori V, Cheremisina A, Shevyakova NI, Radyukina N, Kuznetsov VV, Zacchini M (2015) Evaluation of nickel tolerance in Amaranthus paniculatus L. plants by measuring photosynthesis, oxidative status, antioxidative response and metal-binding molecule content. Environ Sci Pollut Res 22:482-494. https://doi.org/10. 1007/s11356-014-3349-y

Poorter H, Niinemets Ü, Poorter L et al (2009) Causes and consequences of variation in leaf mass per area (LMA): a meta-analysis. New Phytol 182:565-588. https://doi.org/10.1111/j.1469-8137.2009. 02830.x

Qin L, Kang W, Qi Y et al (2016) The influence of silicon application on growth and photosynthesis response of salt stressed grapevines (Vitis vinifera L.). Acta Physiol Plant 38:68. https://doi.org/10. 1007/s11738-016-2087-9

Rajewska I, Talarek M, Bajguz A (2016) Brassinosteroids and response of plants to heavy metals action. Front Plant Sci 7:1-5. https://doi. org/10.3389/fpls.2016.00629

Reeves RD, Baker AJM, Becquer T et al (2007) The flora and biogeochemistry of the ultramafic soils of Goiás state, Brazil. Plant Soil 293:107-119. https://doi.org/10.1007/s11104-007-9192-x

Rehman MZ, Rizwan M, Ali S et al (2016) Contrasting effects of biochar, compost and farm manure on alleviation of nickel toxicity in maize (Zea mays L.) in relation to plant growth, photosynthesis and metal uptake. Ecotoxicol Environ Saf 133:218-225. https://doi.org/10. 1016/j.ecoenv.2016.07.023

Ribeiro MAQ, Almeida A-AF, Mielke MS et al (2013) Aluminum effects on growth, photosynthesis, and mineral nutrition of cacao genotypes. J Plant Nutr 36:1161-1179. https://doi.org/10.1080/ 01904167.2013.766889

Ribeiro AT, Oliveira VP, Barros Junior UO, Silva BRS, Batista BL, Lobato AKS (2019) Data linked to publication entitled 24Epibrassinolide mitigates nickel toxicity in young Eucalyptus urophylla S.T. Blake plants: nutritional, physiological, biochemical, anatomical and morphological responses. V2. Zenodo. [dataset]. https://doi.org/10.5281/zenodo.3552032

Rio LA, Corpas FJ, Sandalio L et al (2003) Plant peroxisomes, reactive oxygen metabolism and nitric oxide. IUBMB Life 55:71-81. https:// doi.org/10.1080/1521654031000094694

Rouached H, Secco D, Arpat BA (2010) Regulation of ion homeostasis in plants: current approaches and future challenges. Plant Signal Behav 5:501-502. https://doi.org/10.4161/psb.11027

Saad R, Kobaissi A, Robin C et al (2016) Nitrogen fixation and growth of Lens culinaris as affected by nickel availability: a pre-requisite for optimization of agromining. Environ Exp Bot 131:1-9. https://doi. org/10.1016/j.envexpbot.2016.06.010

Sagardoy R, Vázquez S, Florez-Sarasa ID, Albacete A, Ribas-Carbó M, Flexas J, Abadía J, Morales F (2010) Stomatal and mesophyll conductances to $\mathrm{CO} 2$ are the main limitations to photosynthesis in sugar beet (Beta vulgaris) plants grown with excess zinc. New Phytol 187: 145-158. https://doi.org/10.1111/j.1469-8137.2010.03241.x

Santos EF, Santini JMK, Paixão AP et al (2017) Physiological highlights of manganese toxicity symptoms in soybean plants: Mn toxicity responses. Plant Physiol Biochem 113:6-19. https://doi.org/10. 1016/j.plaphy.2017.01.022

Santos LR, Batista BL, Lobato AKS (2018) Brassinosteroids mitigate cadmium toxicity in cowpea plants. Photosynthetica 56:591-605. https://doi.org/10.1007/s11099-017-0700-9

Schmidt SB, Jensen PE, Husted S (2016) Manganese deficiency in plants: the impact on photosystem II. Trends Plant Sci 21:622-632. https:// doi.org/10.1016/j.tplants.2016.03.001
Segatto FB, Bisognin DA, Benedetti M et al (2004) A technique for the anatomical study of potato leaf epidermis. Ciência Rural 34:15971601. https://doi.org/10.1590/S0103-84782004000500042

Seldimirova OA, Bezrukova MV, Galin IR, Lubyanova AR, Shakirova FM, Kruglova NN (2017) 24-epibrassinolide effects on in vitro callus tissue formation, growth, and regeneration in wheat varieties with contrasting drought resistance. Russ J Plant Physiol 64:919 929. https://doi.org/10.1134/S1021443717060085

Sellami R, Gharbi F, Rejeb S, Rejeb MN, Henchi B, Echevarria G, Morel JL (2012) Effects of nickel hyperaccumulation on physiological characteristics of alyssum Murale grown on metal contaminated waste amended soil. Int J Phytoremediation 14:609-620. https:// doi.org/10.1080/15226514.2011.619225

Seregin IV, Kozhevnikova AD (2006) Physiological role of nickel and its toxic effects on higher plants. Russ J Plant Physiol 53:257-277. https://doi.org/10.1134/S1021443706020178

Sharma A, Dhiman A (2013) Nickel and cadmium toxicity in plants. J Pharm Sci Innov 2:20-24. https://doi.org/10.7897/2277-4572. 02213

Sharma I, Pati PK, Bhardwaj R (2011) Effect of 24-epibrassinolide on oxidative stress markers induced by nickel-ion in Raphanus sativus L. Acta Physiol Plant 33:1723-1735. https://doi.org/10.1007/ s11738-010-0709-1

Sharma P, Jha AB, Dubey RS, Pessarakli M (2012) Reactive oxygen species, oxidative damage, and antioxidative defense mechanism in plants under stressful conditions. J Bot 2012:1-26. https://doi. org $/ 10.1155 / 2012 / 217037$

Sharma A, Thakur S, Kumar V, Kesavan AK, Thukral AK, Bhardwaj R (2017) 24-epibrassinolide stimulates imidacloprid detoxification by modulating the gene expression of Brassica juncea L. BMC Plant Biol 17:1-10. https://doi.org/10.1186/s12870-017-1003-9

Shutilova NI (2010) The oxygen-evolving complex of chloroplast membranes. Biochem Suppl Ser A Membr Cell Biol 4:125-133. https:// doi.org/10.1134/S1990747810020017

Siddiqui H, Hayat S, Bajguz A (2018) Regulation of photosynthesis by brassinosteroids in plants. Acta Physiol Plant 40:1-15. https://doi. org/10.1007/s11738-018-2639-2

Silva EN, Ribeiro RV, Ferreira-Silva SL et al (2012) Coordinate changes in photosynthesis, sugar accumulation and antioxidative enzymes improve the performance of Jatropha curcas plants under drought stress. Biomass Bioenergy 45:270-279. https://doi.org/10.1016/j. biombioe.2012.06.009

Sirhindi G, Mir MA, Abd-Allah EF et al (2016) Jasmonic acid modulates the physio-biochemical attributes, antioxidant enzyme activity, and gene expression in Glycine max under nickel toxicity. Front Plant Sci 7:1-12. https://doi.org/10.3389/fpls.2016.00591

Soares C, de Sousa A, Pinto A et al (2016) Effect of 24-epibrassinolide on ROS content, antioxidant system, lipid peroxidation and Ni uptake in Solanum nigrum L. under Ni stress. Environ Exp Bot 122:115125. https://doi.org/10.1016/j.envexpbot.2015.09.010

Sorin C, Musse M, Mariette F, Bouchereau A, Leport L (2015) Assessment of nutrient remobilization through structural changes of palisade and spongy parenchyma in oilseed rape leaves during senescence. Planta 241:333-346. https://doi.org/10.1007/s00425$014-2182-3$

Sreekanth TVM, Nagajyothi PC, Lee KD, Prasad TNVKV (2013) Occurrence, physiological responses and toxicity of nickel in plants. Int J Environ Sci Technol 10:1129-1140. https://doi.org/10.1007/ s13762-013-0245-9

Steel RG, Torrie JH, Dickey DA (2006) Principles and procedures of statistics: a biometrical approach, 3rd edn. Academic Internet Publishers, Moorpark

Tadele D, Teketay D (2014) Growth and yield of two grain crops on sites former covered with eucalypt plantations in Koga watershed, northwestern Ethiopia. J For Res 25:935-940. https://doi.org/10.1007/ s11676-014-0483-9 
Vázquez MN, Guerrero YR, González LM, Noval WT (2013) Brassinosteroids and plant responses to heavy metal stress. An overview. Open J Met 3:34-41. https://doi.org/10.4236/ojmetal.2013. 32A1005

Velikova V, Yordanov I, Edreva A (2000) Oxidative stress and some antioxidant systems in acid rain-treated bean plants protective role of exogenous polyamines. Plant Sci 151:59-66. https://doi.org/10. 1016/S0168-9452(99)00197-1

Velikova V, Tsonev T, Loreto F, Centritto M (2011) Changes in photosynthesis, mesophyll conductance to $\mathrm{CO} 2$, and isoprenoid emissions in Populus nigra plants exposed to excess nickel. Environ Pollut 159:1058-1066. https://doi.org/10.1016/j.envpol.2010.10.032

Wu Q-S, Xia R-X, Zou Y-N (2006) Reactive oxygen metabolism in mycorrhizal and non-mycorrhizal citrus (Poncirus trifoliata) seedlings subjected to water stress. J Plant Physiol 163:1101-1110. https://doi.org/10.1016/j.jplph.2005.09.001

Yusuf M, Fariduddin Q, Hayat S, Hasan SA, Ahmad A (2011a) Protective response of 28-homobrassinolide in cultivars of triticum aestivum with different levels of nickel. Arch Environ Contam Toxicol 60:6876. https://doi.org/10.1007/s00244-010-9535-0
Yusuf M, Fariduddin Q, Hayat S, Ahmad A (2011b) Nickel: an overview of uptake, essentiality and toxicity in plants. Bull Environ Contam Toxicol 86:1-17. https://doi.org/10.1007/s00128-010-0171-1

Yusuf M, Fariduddin Q, Ahmad A (2012) 24-Epibrassinolide modulates growth, nodulation, antioxidant system, and osmolyte in tolerant and sensitive varieties of Vigna radiata under different levels of nickel: a shotgun approach. Plant Physiol Biochem 57:143-153. https://doi.org/10.1016/j.plaphy.2012.05.004

Yusuf M, Fariduddin Q, Ahmad I, Ahmad A (2014) Brassinosteroidmediated evaluation of antioxidant system and nitrogen metabolism in two contrasting cultivars of Vigna radiata under different levels of nickel. Physiol Mol Biol Plants 20:449-460. https://doi.org/10. 1007/s12298-014-0259-x

Zhou YM, Han SJ (2005) Photosynthetic response and stomatal behaviour of Pinus koraiensis during the fourth year of exposure to elevated CO2 concentration. Photosynthetica 43:445-449. https://doi. org/10.1007/s11099-005-0071-5

Publisher's note Springer Nature remains neutral with regard to jurisdictional claims in published maps and institutional affiliations. 